\title{
Otomorphs (= otocephalans or ostarioclupeomorphs) revisited
}

\author{
Gloria Arratia
}

A morphological revision is presented here on the cohort Otomorpha, a clade currently interpreted as the most primitive among the large supercohort Clupeocephala. Otomorpha is a morphologically heterogeneous group represented by clupeiforms, alepocephaliforms, and ostariophysans (gonorynchiforms, cypriniforms, characiforms, siluriforms, and gymnotiforms) that inhabit various marine and freshwater environments worldwide. Otomorphs have a long (ca. $145 \mathrm{Ma}$ ) and diverse fossil record. They are the largest fish teleostean clade worldwide, as well as the largest of the Neotropical Region. While molecular studies strongly confirm the monophyly of Otomorpha, most potential morphological synapomorphies of the group become homoplastic largely due to the peculiar morphological character states (either losses or transformations) present in alepocephaliforms. The fusion of haemal arches with their respective vertebral centra anterior to preural centrum 2 stands as an unambiguous synapomorphy of the clade. The ankylosis or fusion of the extrascapular and parietal bones, and silvery areas associated with the gas bladder are also interpreted as synapomorphies, although they are homoplastic characters mainly due to secondary losses or further transformations of the morphological features in the alepocephaliforms.

Keywords: Alepocephaloids, Clupeomorphs, Morphology, Ostariophysans, Synapomorphies.

Se realizó una revisión morfológica de la cohorte Otomorpha la que se interpreta como el grupo más primitivo dentro de la gran supercohorte Clupeocephala. Otomorpha incluye peces con una gran diversidad corporal la que está representada por clupeiformes, alopocefáliformes y ostariofisos (gonorinchiformes, cipriniformes, caraciformes, siluriformes y gimnotiformes), los que habitan diversos ambientes marinos y de aguas continentales del planeta. Otomorfos son el grupo de peces más grande a nivel mundial y al mismo tiempo, el más grande de la Región Neotropical. Mientras estudios moleculares confirman la monofilia de Otomorfa, la mayoría de las sinapomorfías morfológicas del grupo se interpretan como homoplásticas debido fundamentalmente a la naturaleza peculiar de ciertos caracteres morfológicos (ya sea pérdidas o transformación de estados de caracteres) de alepocefaliformes. La fusión de los arcos hemales con sus respectivos centros vertebrales anterior al centro preural 2 es una sinapomorfía de la cohorte. La anquilosis o fusión de los huesos extrascapular y parietal y la presencia de áreas plateadas asociadas con la vejiga natatoria son interpretados como sinapomorfías, independientemente de que son caracteres homoplásticos debido a pérdidas o transformaciones de tales caracteres en los alepocefáliformes.

Palabras claves: Alepocefálidos, Clupeomorfos, Morfología, Ostariofisos, Sinapomorfías.

\section{Introduction}

The largest neopterygian clade, the Infraclass Teleostei, has undergone major changes in the last 20 years mainly due to the development of molecular techniques and studies that changed the content, position and phylogenetic interpretations of numerous clades that were historically based on morphological characters (Arratia, 2015); changes in the Teleostei tree include the recognition of new taxa and the deletion of some nominal orders and families. Such new approaches, plus the discoveries of new fossil taxa and re-evaluation of others, have given a new understanding in age, content and evolutionary changes of the Infraclass Teleostei of Betancur-R. et al. (2017) or the Division Teleosteomorpha of Arratia (2001, 2013, 2017) and Nelson et al. (2016) or the Subdivision Teleostei of Nelson et al. (2016), despite the assignment of this group to various high-level ranks. An excellent example of major changes revealed by molecular studies is the present content and classification of internal groups comprising the large supercohort Clupeocephala versus previous classifications in Nelson's Fishes of the World (1994, 2006). Independent of the major developments and changes from molecular studies and the discovery of new fossils, morphological studies of extant and fossil taxa still play a major, unique role in providing the characters that support the monophyly of taxa and taxonomic diagnoses (Arratia, 2015). Elopomorpha is currently interpreted as the most primitive taxon and the sister of Osteoglossomorpha plus Clupeocephala in the crown group Teleostei (or Teleocephala of de Pinna, 1996 or Osteoglossocephala of Arratia 1999 or Osteoglossocephalai of Betancur-R et al., 2017). This phylogenetic hypothesis is supported by morphologi- 
cal and molecular studies (Arratia, 1997, 1999, 2013, 2017; Near et al., 2012; Betancur-R et al., 2013, 2017).

Currently, the supercohort Clupeocephala sensu Arratia (2010) includes the cohorts Otomorpha (sensu Wiley, Johnson, 2010 and Betancur-R et al., 2017 or Otocephala of Johnson, Patterson, 1996 or Ostarioclupeomorpha of Arratia 1996, 1997, 1999) and Euteleosteomorpha (sensu Betancur-R et al., 2017 or Euteleostei sensu Johnson, Patterson, 1996). The taxon Clupeocephala was erected by Patterson, Rosen (1977) to contain the Clupeomorpha (e.g., engraulids, clupeids, and pristigasterids) and the Euteleostei (e.g., cyprinids, catfishes, salmonids, atherinids, and cyprinodontids), in other words, the majority of extant teleosts. This interpretation of Clupeocephala represented the approach of the time based on morphological evidence, and it was accepted until 1996, when our understanding of primitive clupeocephalans was changed by both molecular and morphological evidence.

Until the 1970s, ostariophysans and gonorynchiforms were interpreted as disparate groups within the Euteleostei, following mainly the phylogenetic hypothesis of Greenwood et al. (1966: their Division III). Gonorynchiforms were accepted as part of the ostariophysans after the work of Rosen, Greenwood (1970), and consequently, under this new understanding, the Ostariophysi continued being interpreted as Euteleostei, an interpretation that was also followed by Fink, Fink (1981), who assumed that ostariophysans were primitive euteleosts sensu Patterson, Rosen (1977). The interpretation of ostariophysans as euteleosts was supported by numerous morphological studies published between the 1970s and 1990s where ostariophysans appeared nested with esocoids, argentinoids, osmerids and/or salmonids (see Fig. 1a-h).

Starting in 1993, the relationships of ostariophysans were challenged when a sister relationship with clupeomorphs was proposed by molecular analyses of Lê et al. (1993) and Lecointre (1993). Although Lecointre, Nelson (1996; see Fig. 1h) proposed a sister relationship between clupeomorphs and ostariophysans based on molecular data from others, they proposed four morphological characters as possible synapomorphies supporting monophyly of the assem-
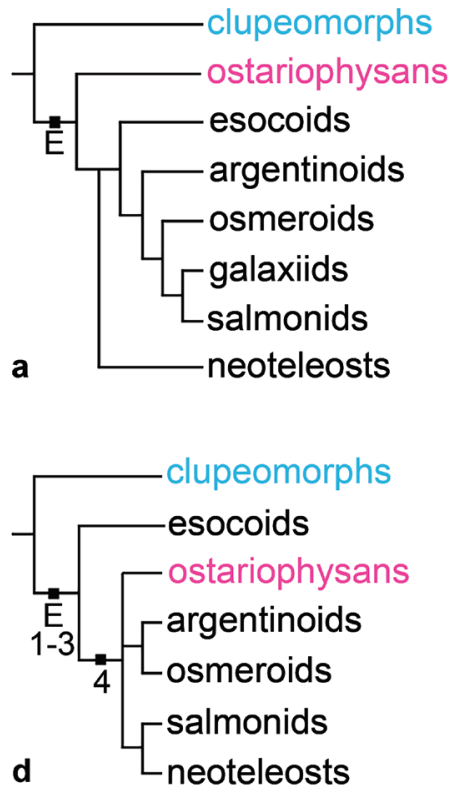
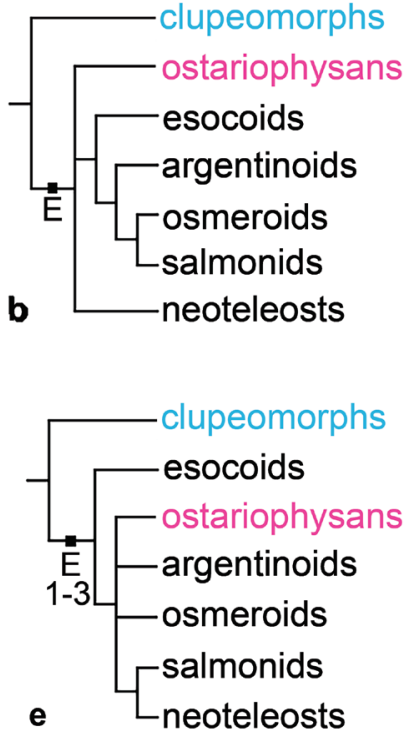
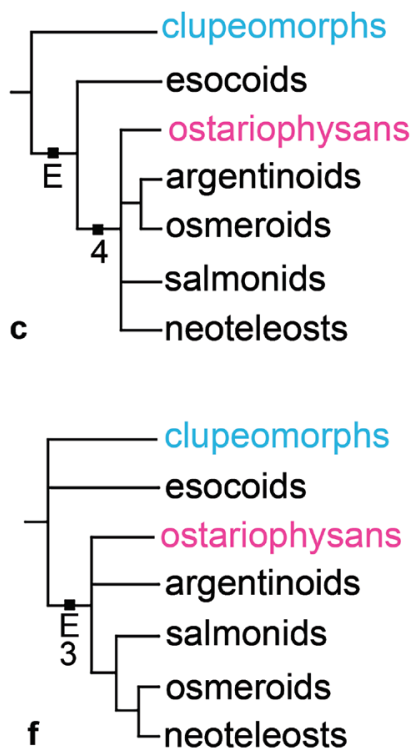
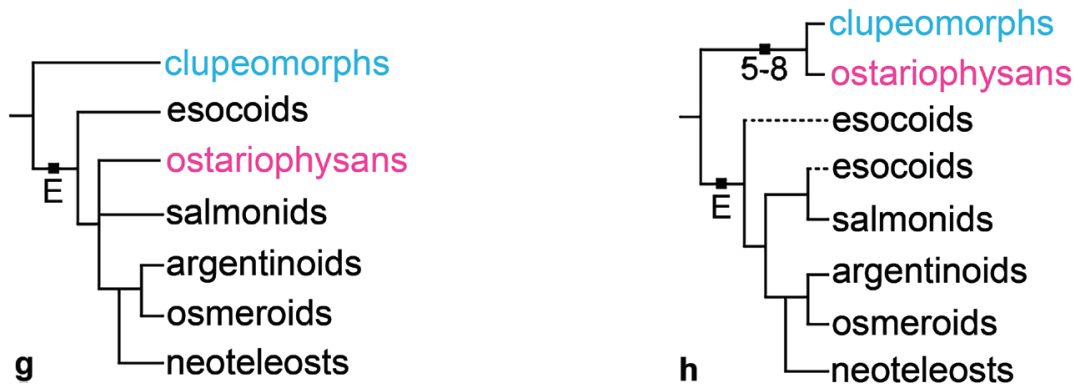

Fig. 1. Clupeocephalan relationships proposed from 1973 to 1994. a. after Rosen 1973, 1974; b. after Rosen, 1982; c. after Fink, Weitzman, 1982; d. after Lauder, Liem, 1983; e. after Fink, 1984; f. after Rosen, 1985; g. after Begle, 1991, 1992; h. after Lecointre, Nelson, 1996. $\mathbf{E}=$ Euteleostei. Characters $\mathbf{1}$ = nuptial tubercles; $\mathbf{2}=$ stegural; $\mathbf{3}=$ adipose fin; $\mathbf{4}=$ absence of tooth plate over basibranchial $4 ; \mathbf{5}$ = pleurostyle; $\mathbf{6}=$ fusion of hypural 2 with first ural centrum; 7 = fusion of extrascapulars and parietal bones; $\mathbf{8}$ = fusion of hemal arches and centra anterior to preural centrum 2. (Modified from Lecointre, Nelson, 1996: fig. 1). 
blage, but did not name that new clade. This was done by Johnson, Patterson (1996; Fig. 2a), in the same volume where Lecointre, Nelson (1996) published their results. Arratia (1996, 1997, 1999), based on morphological studies of fossil $(\dagger)$ and extant teleosts, also proposed a sister group relationship between Ostariophysi and Clupeomorpha, naming that clade as the Ostarioclupeomorpha (Figs. 2a, 3). Arratia (1997) also introduced the stem ostariophysan $\dagger$ Tischlingerichthys from the Upper Jurassic of Germany, which indicates an age of at least ca. $145 \mathrm{Ma}$ for the clade. Subsequent molecular studies, in addition, found a close relationship between otocephalans and alepocephaliforms, but with a different arrangement within the subgroups. While Ishiguro et al. (2003) proposed alepocephaliforms embedded in a paraphyletic Otocephala, Lavoué et al. (2005) proposed an unresolved trichotomy comprised of clupeomorphs, alepocephaliforms, and ostariophysans (Fig. 2b). Recent molecular studies (Near et al., 2012; Betancur-R et al., 2013; Betancur-R et al., 2017) support a monophyletic Otomorpha (a new name), including the clupeomorphs as the sister of the alepocephaliforms + ostariophysans (Fig. 2c).

Although the inclusion of alepocephaliforms within the cohort Otomorpha has been proposed by different molecular studies, there is no morphological synapomorphy supporting the monophyly of Otomorpha comprising the subcohorts Clupei (= Clupeomorpha of Greenwood et al., 1966), Alepocephali, and Ostariophysi (but see below the section on Analysis of characters). Consequently, the main goal of this contribution is to search for and discuss potential morphological synapomorphies of this clade. A brief introduction on the three taxa is presented below.

\section{Content of Otomorpha}

The name Otomorpha was introduced by Wiley, Johnson (2010) as synonym of Otocephala of Johnson, Patterson (1996) and Ostarioclupeomorpha of Arratia $(1997,1999)$ so that in this context Otomorpha contains only Clupeomorpha and Ostariophysi. Betancur-R et al. (2017) retained the name Otomorpha, but included three main groups: clupeiforms, ostariophysans, and alepocephaliforms, whereas Nelson et al. (2016) retained the name Otocephala but added alepocephaloids. Thus, Otomorpha varies in content depending on time and authorship. Otomorpha is defined here as the clade containing clupeiforms, ostariophysans and alepocephaliforms (Fig. 4a-g). The original taxonomic content of Otocephala or Ostarioclupeomorpha is retained here, i.e., the clade including only clupeomorphs and ostariophysans. Otomorpha is the most primitive clade in Clupeocephala with about 11,000 extant species, 1,500 extant genera, and 90 extant families, making it one of the largest clades among the crown-group Teleostei.

Extant otomorphs are primarily freshwater fishes, including most otophysans, most gonorynchiforms (ca. 80\%), and a few clupeomorphs (ca. 10\%). They are the richest components of the Neotropical Region, extending from

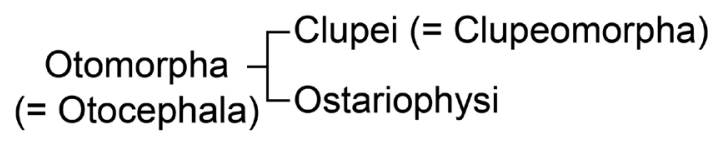

a

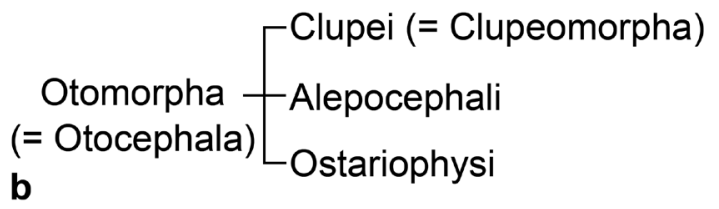

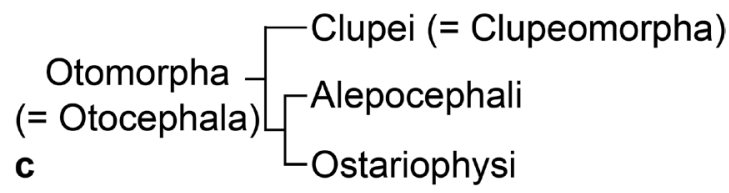

Fig. 2. Hypotheses of Otomorpha relationships according to molecular and morphological evidence (a) and only molecular evidence (b and c). a. after Lé et al., 1993; Lecointre, 1993; Lecointre, Nelson, 1996; Arratia 1996, 1997, 1999, 2010; Wiley, Johnson, 2010; b. after Lavoué et al., 2005, Lavoué et al., 2008; Poulsen et al., 2009; c. after Near et al., 2012; Betancur-R. et al., 2013; Betancur-R. et al., 2017.

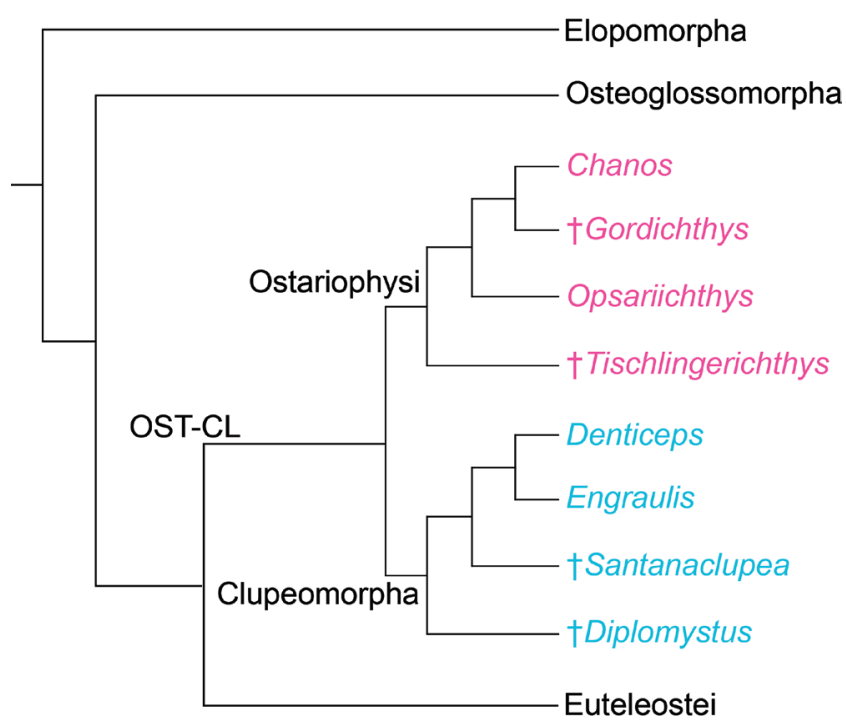

Fig. 3. Hypothesis of phylogenetic relationships of the Ostarioclupeomorpha (= OST-CL; Otocephala) among the crown Teleostei, based on fossil $(\dagger)$ and recent teleosts (abbreviated from Arratia, 1999:fig. 19).

southern Mexico to the southernmost region of temperate South America, with an extraordinary diversification of siluriforms and characiforms, including gymnotiforms, which are unique to the region. While the cypriniforms are present in the southern part of North America and Central America, they are not native members of South America [A piece of a fossil bone was interpreted by Gayet (1982) as a palate bone of a supposedly cyprinid named $\dagger$ Molinichthys inopinatus from the Late Cretaceous of Bolivia; a view 

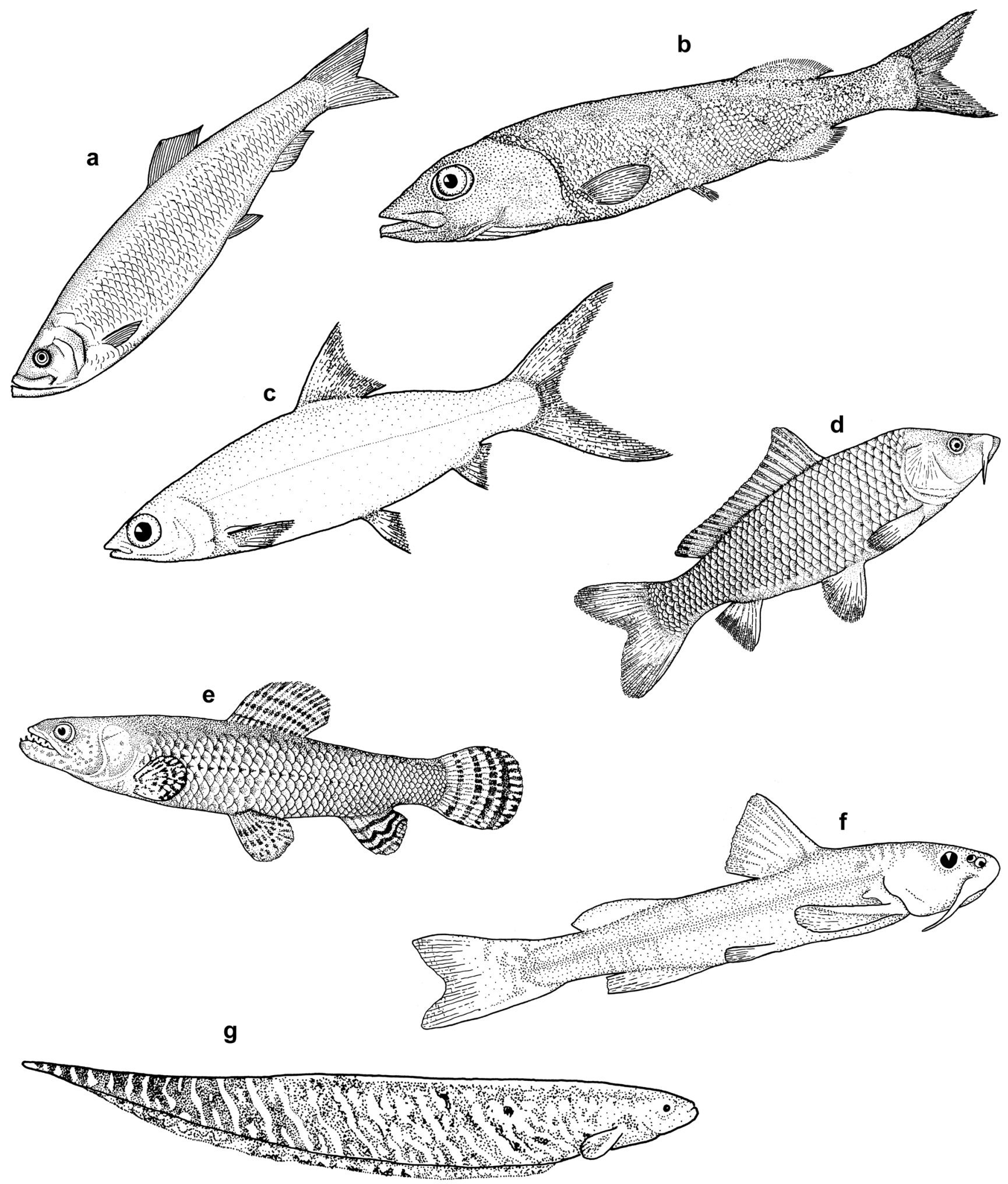

Fig. 4. Diagrammatic representation of different otomorph groups such as: a. clupeiformes; b. alepocephaliforms; c. gonorynchiforms; d. cypriniforms; e. characiforms; f. siluriforms; g. gymnotiforms.

that has not been corroborated (Arratia, Cione, 1996; Fink, Fink, 1996)]. In contrast to most otophysans, clupeomorphs and alepocephaliforms are mainly or exclusively marine forms, respectively.
The oldest-known otomorph, †Tischlingerichthys (Fig. 5 a), was recovered in marine sediments from the Upper Jurassic, Upper Tithonian of the Mörnsheim Formation, Bavaria, Germany (Arratia, 1997; Arratia, Schultze, 2015). 

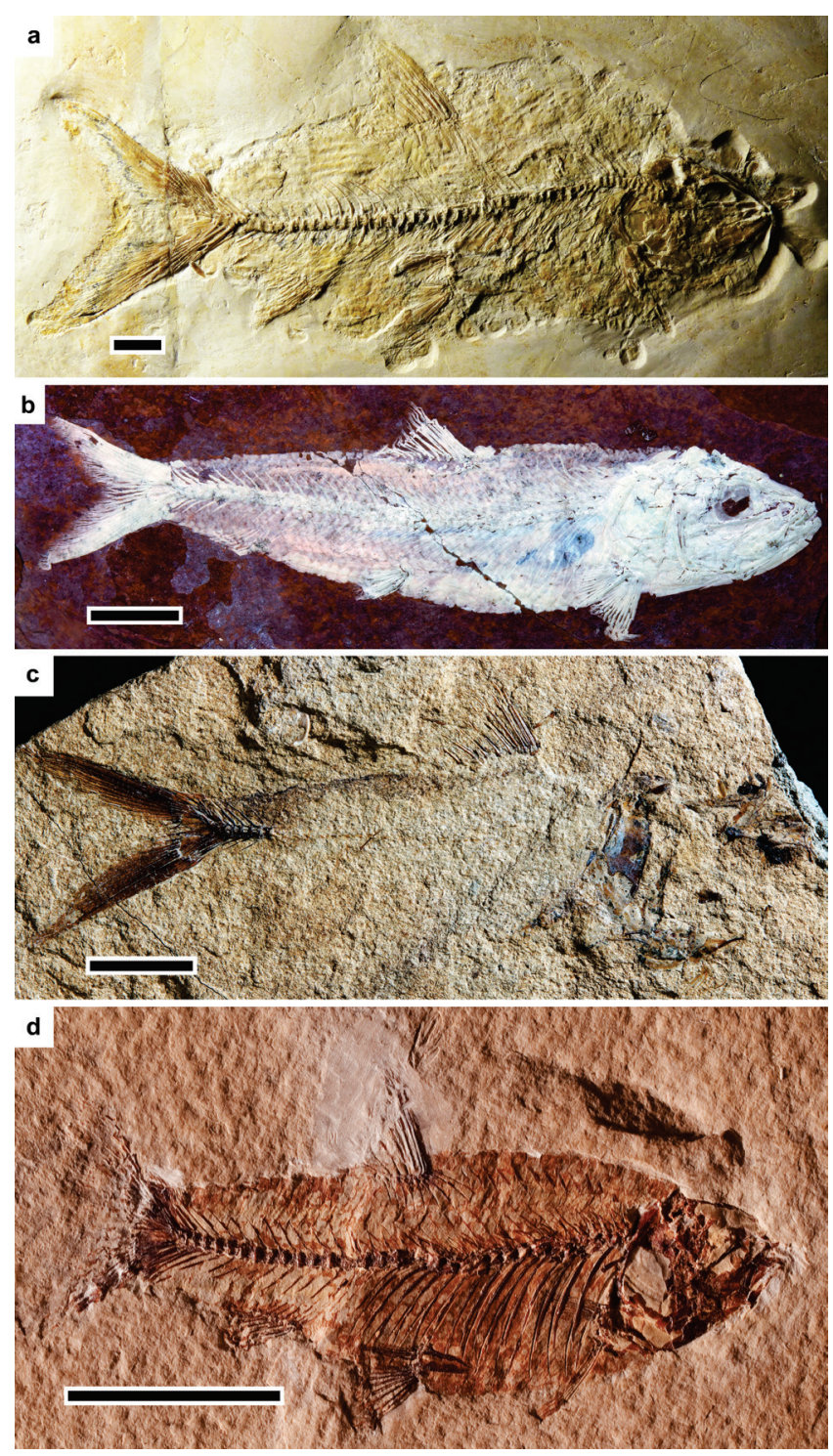

Fig. 5. Fossil otomorphs in lateral view. a. ostariophysan incertae sedis †Tischlingerichthys viohli Arratia, 1997; Upper Jurassic, Germany; holotype JM-E Moe 8; photograph courtesy of H. Tischlinger; b. clupeomorph $\uparrow$ Santanaclupea silvasantosi Maisey, 1993; Lower Cretaceous, Brazil; paratype DNPM DGM1338-P; photograph courtesy of D. Mayrinck; c. clupeomorph $\uparrow$ Ranulfoichthys dorsonudum Alvarado-Ortega, 2014; Lower Cretaceous, Mexico; paratype IGM 9034; photograph courtesy of J. Alvarado-Ortega; d. gonorynchiform $\uparrow$ Gordichthys conquensis Poyato-Ariza, 1994; holotype MCCM-LH-1228; Lower Cretaceous, Spain; photograph by J.A. Gracia; courtesy by F.J. Poyato-Ariza. Scale bars $=1 \mathrm{~cm}$.

Other comparatively younger otomorphs (Early Cretaceous) have been recovered in marine, estuarine and/or freshwater, including the oldest marine gonorynchid (†Sapperichthys from Cenomanian strata of Mexico; Amaral et al., 2013) and a clupeomorph that has been interpreted as the most primitive within the group (Fig. 5b; †Ranulfoichthys from marine Albian strata of Mexico; Alvarado-Ortega, 2014). In com- parison, Denticipitoidei is a younger group, with the oldest representatives- $\uparrow$ Paleodenticeps tanganikae Greenwood, 1960 and $\dagger$ Paleodenticeps sp. (Fig. 6)- known from deposits in Mahenge, Tanzania, which are assigned an Eocene age (about $46 \mathrm{Ma}$; Harrison et al., 2001; Kaiser et al., 2006). Although gonorynchiforms were well represented in the Lower Cretaceous of the Neotropical region, being very abundant in Brazilian basins (for a review see Brito, Amaral, 2008), modern forms do not inhabit the Neotropical Region, except, perhaps, for Chanos, which has an Indo-Pacific distribution that extends from California to Ecuador (although this distribution may show strong periodic changes associated with the El Niño/La Niña currents).

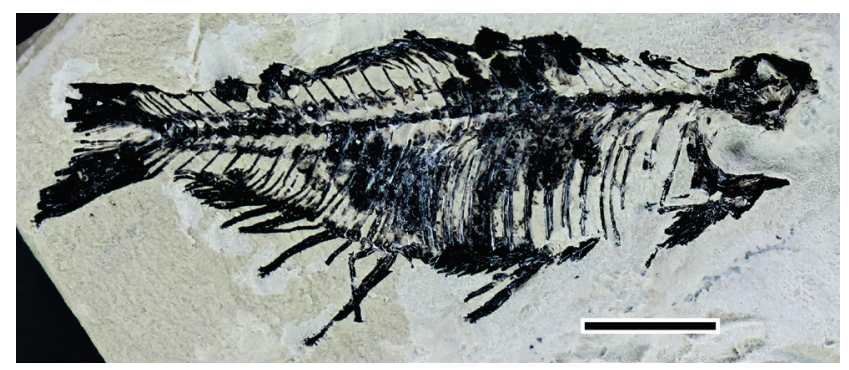

Fig. 6. Fossil otomorph in lateral view: $\uparrow$ Paleodenticeps sp.; Eocene, Mahenge, Tanzania (MB uncatalogued); photograph courtesy of C. Quezada-Romegialli. Scale bar equals $5 \mathrm{~mm}$.

Numerous important fossils representing some stem clupeomorphs (e.g., †Santanaclupea silvasantosi; Fig. 5c) and otophysans are known from Lower Cretaceous strata of the Neotropical Region, especially Brazil, and others with peculiar cranial morphologies -and still unknown phylogenetic relationships within siluriforms- are known from the Cretaceous-Paleocene of Bolivia (Arratia, Gayet, 1985).

Clupei. Clupei (sensu Betancur-R et al., 2017) or Clupeiformes are characterized by a series of characters, with the most conspicuous being an otophysic connection between the swim bladder and inner ear involving a pair of anterior extensions of the swim bladder that enters the skull through the exoccipital to connect with the utriculus of the inner ear, forming ossified bullae in the prootic, and usually also in the pterotic too; base of hypural 2 fused to ural centrum 2 (= of polyural terminology sensu Schultze, Arratia, 2013; Wiley et al., 2015) from early ontogenetic stages and an autogenous hypural 1 without connection with the vertebral column from early ontogeny; one or more abdominal scutes (including pelvic scutes), each of a single element that crosses the ventral midline; and development of dorsal scutes with a median keel. For other characters see Grande (1985), Di Dario (2004), and Di Dario, de Pinna (2006) and the compilation of synapomorphies by Wiley, Johnson (2010).

The clupeiforms are represented by about 400 extant species in ca. 90 genera and five families (Nelson et al., 2016) and an extensive fossil record, extending back to the 
Early Cretaceous (e.g., Grande, 1985; Malabarba, Di Dario, 2017). Two extant suborders (Denticipitoidei and Clupeoidei) and a fossil one (†Ellimmichthyioidei) are currently recognized (Nelson et al., 2016). Clupeiforms have a worldwide distribution. They typically inhabit marine water, but about 80 species are primarily freshwater. Many species are economically important (e.g., Whitehead, 1985; Whitehead et al., 1988; Lavoué et al., 2014).

Despite the biological and economic importance of the group, it is remarkable that the only comprehensive study including fossil and extant species supporting the monophyly of the group was published a few decades ago (Grande, 1985). Only few studies, either morphological (Di Dario, 2002, 2004, 2009; Di Dario, de Pinna, 2006; de Pinna, Di Dario, 2010) or molecular (Li, Orti, 2007; Lavoué et al., 2013; Bloom, Lovejoy, 2014), were published on extant clupeomorphs during this period. In contrast, contributions on fossils have maintained the attention on the group, either on potentially oldest representatives, analyses of characters, and/or past biogeographical patterns of distribution (Maisey, 1993; Chang, Maisey, 2003; Zaragueta-Basil, 2004; Forey, 2004; Alvarado-Ortega et al., 2008; Murray, Wilson, 2013; Alvarado-Ortega, 2014; Malabarba, Di Dario, 2017).

Ostariophysi. Ostariophysans are characterized by numerous features, with only a few listed here: basisphenoid absent; sacculi and lagena with a posterior position and nearer midline; dermal portion of the palatine (= dermopalatine) absent and represented only by the autopalatine; gas bladder divided into smaller anterior and larger posterior chambers; presence of a unique alarm substance in epidermis (absent in gymnotiforms, with electrical signaling); and presence of nuptial tubercles with well-developed keratinous caps. For other characters and comments see Fink, Fink $(1981,1996)$, Fink et al. (1984), Lecointre, Nelson (1996), and Wiley, Johnson (2010).

Ostariophysans (Fig. 4c-g) comprise ca. 10,400 species contained in about 1,350 genera, 80 families and five orders (Nelson et al., 2016) included in two sections, Anatophysa (sensu Betancur-R et al., 2017 or Anatophysi of Fink, Fink, 1981), which contains Gonorynchiformes and Otophysa (sensu Betancur-R et al., 2017 or Otophysi of Fink, Fink, 1981), which in turn, includes Cypriniformes, Characiformes, Siluriformes, and Gymnotiformes. Although there are differences between morphological and most molecular phylogenetic hypotheses of the orders, there is now consensus concerning the monophyly of the group (Fink, Fink, 1981, 1996; Betancur-R et al., 2017; Arcila et al., 2017) and also of the otophysans. Major differences include: (1) a few molecular studies have questioned the monophyly and relationships of the Characiformes (Nakatani et al., 2011; Chen et al., 2013; Chakrabarty et al., 2017), but monophyly of the group and its position as the sister to Gymnotiformes + Siluriformes was recently supported by other molecular studies (Arcila et al., 2017; Betancur-R et al., 2017); (2) the family Diplomystidae appears as the most primitive catfish group in morphological studies of Siluriformes (e.g., Arratia, 1987; Grande, 1987), whereas Nematogenyidae plus other loricarioids is the sister to Diplomystidae plus all other catfishes in molecular studies (e.g., Sullivan et al., 2006; Arcila et al., 2017; Betancur-R et al., 2017). For other references on the subject see Arratia, Quezada-Romegialli (2017). Most extant ostariophysans are primarily freshwater fishes with a global distribution (except Antarctica, Greenland, and New Zealand), but there are about 120 marine species restricted to the Siluriformes (Nelson et al., 2016). Numerous fossils interpreted as possible stem taxa have been recovered in marine or estuarine strata, a fact that opens interesting questions concerning the evolution of the environment of Ostariophysi or of its particular orders.

Contrary to the current state of clupeiform research, ostariophysans -fossil and extant species- receive an enormous amount of attention, especially those living in the Neotropical Region; this is reflected in hundreds of publications produced by special projects, such as the "All Catfish Species Inventory" and "Cypriniformes Tree of Life" and other special publications (Malabarba et al., 1998; Reis et al., 2003; Arratia et al., 2003; Grande et al., 2010; Albert, Reis, 2011).

The oldest known ostariophysan is the Late Jurassic $\uparrow$ Tischlingerichthys viohli from Germany, which is interpreted as incertae sedis (Fig. 5a). Numerous Early Cretaceous ostariophysans belonging to the Gonorynchiformes are known from Spain and Brazil [e.g., †Rubiesichthys, †Gordichthys (Fig. 5d), and $\dagger$ Dastilbe; see Dietze, 2007; Brito, Amaral, 2008; Poyato-Ariza et al., 2010] and Mexico (†Sapperichthys; Amaral et al., 2013). Additionally, $\dagger$ Chanoides macropoma from the Middle Eocene of Monte Bolca, Italy and $\uparrow N a r d o$ noides chardoni from the Upper Cretaceous of Nardò have recently been confirmed as stem otophysans (Mayrinck et al., 2015a). Restudy of $\uparrow$ Santanichthys diasii from the Early Cretaceous (Albian) of Brazil, which was previously described as the oldest characiform (Filleul, Maisey, 2004), has been re-interpreted as a stem otophysan (Malabarba, Malabarba, 2010). †Salminops ibericus from the Cenomanian of Portugal previously described as one of the oldest characiforms (Gayet, 1985) is not an ostariophysan, but possibly a crossognathiform (Mayrinck et al., 2015b), and $\dagger$ Sorbinicharax verraesi from the Upper Cretaceous of Nardò, Italy, previously interpreted as another characiform, has been re-interpreted as Teleostei incertae sedis by Mayrinck et al. (2017).

Alepocephali. Alepocephaliforms (Fig. 4b) are characterized by the presence of parietal bones [of traditional terminology] separated by the supraoccipital; branchiostegal cartilages; one postcleithrum; epipleural bones extending forward to about abdominal vertebra 3; opercle reduced dorsally and by several absent structures such as posttemporal fossa; gas bladder; adipose fin; and urodermal bone (Johnson, Patterson, 1996). Although general descriptions of some alepocephaliform structures, such as the skull roof bones, crumeral organs, and caudal skeletons, were published by Greenwood, Rosen (1971), new information on the posterior part of the skull roof, including extrascapulars 
and the ontogenetic transformation of vertebral structures and caudal skeleton, are provided below.

In comparison to clupeiforms and ostariophysans, the Alepocephali comprise a small group of 137 species, 32 genera, three families and one order, all living in marine waters (Nelson et al., 2016). Most species of the assemblage inhabit meso- to bathypelagic environments (Nelson et al., 2016).

Early taxonomic studies associated alepocephaliforms with clupeiforms (e.g., Berg, 1937, 1958; Gosline, 1960) and other primitive teleosts on the basis of common similarities, the traditional approach of the time. However, this can be misleading without completely understanding the order Clupeiformes as defined by Berg, which included not only the suborders Clupeoidei and Alepocephaloidei, but also several other clades, such as $†$ Lycopteroidei, Chanoidei, Phractolaemoidei, and Salmonoidei. During the last 50 years, alepocephaliforms have been traditionally included within the Euteleostei, closer to the salmoniforms (Greenwood et al., 1966; Markle, 1976) or specifically within the Argentinoidei (Greenwood, Rosen, 1971; Lauder, Liem, 1983; Begle, 1992; Johnson, Patterson, 1996; Diogo, 2008; Wiley, Johnson, 2010).

The inclusion of alepocephalids within the argentinoids is based on the presence of a crumenal organ, the descended position of the distal part of the two to four epineurals, and caudal median cartilages supporting the lowermost ray of the upper caudal lobe (Johnson, Patterson, 1996). Although those features are present in alepocephalids and argentinoids, under the new taxonomic interpretations given by molecular studies, they need further revisions. For instance:

1. A crumenal organ is a specialization of alepocephaliforms and argentinoids. It is a posterior branchial structure that was referred to as an epibranchial organ until Greenwood, Rosen (1971) named it "crumenal organ". The main distinction between the crumenal organ and the epibranchial organ is the presence of a distinct accessory cartilage that may have arisen by segmentation from the posterior articular surface of ceratobranchial 5 in alepocephalids and argentinoids (Nelson, 1967; Greenwood, Rosen, 1971) and in Denticeps (de Pinna, Di Dario, 2010). Thus, the finding of this accessory cartilage in Denticeps opened the necessity for extensive comparative studies in various teleosts.

2. The third feature proposed as shared by argentinoids and alepocephalids, the caudal median cartilages supporting the lowermost ray of the upper caudal lobe (Johnson, Patterson, 1996) is controversial due to its variability. The caudal medial cartilages $(\mathrm{mc})$ are commonly associated with the middle principal caudal rays (PR) in argentinoids (mc versus PR10 and 11) and not with the lowermost ray of the upper caudal lobe. The condition as shown in Fig. 7 for Argentina is also found in alepocephalids (see below, the section on Analysis of characters), salmonids (Fujita, 1990; Arratia, Schultze, 1992), and other euteleosts (Fujita, 1990).

3 . The caudal skeleton is a complex structure in need of further investigation in alepocephaliforms (see below, Analysis of characters) and in argentinoids. Unlike most other euteleosts (and also in alepocephaliforms), argentinoids have one vertebral centrum bearing the parhypural and hypurals 1 and 2, a centrum that was interpreted as formed by preural centrum 1 plus ural centrum 1 [of the diural terminology] by Patterson (1970:figs. 38, 40] in Argentina sialis and preural centrum 1 plus ural centrum 1 plus uroneural 1 in Bathylagus antarcticus. However, it is unknown how many vertebral centra form this centrum that I interpret, in a preliminary way, as compound (CC in Fig. 7), but noting that its origin and composition is still unknown (currently under study by GA based on its ontogenetic series). A similar structure has been interpreted as a compound centrum in adult engraulids, e.g., Engraulis and Coilia, where the centrum includes preural centrum 1 plus ural centra 2 and $3+4$ [of the polyural terminology] (Schultze, Arratia, 2013:figs. 18, 19A-D), and in ostariophysans (e.g., Monod, 1968; Lundberg, Baskin, 1969; Fink, Fink, 1981; Schultze, Arratia, 1989, 2013; Fujita, 1990). However, it is unknown whether the structure interpreted as a compound centrum in ostariophysans forms the same way in different ostariophysan subgroups (see Schultze, Arratia, 2013; Wiley et al., 2015). The fossil ostariophysan $\dagger$ Tischlingerichthys also has a long vertebral centrum bearing the parhypural and hypurals 1 and 2 (Arratia, 1997:fig. 67). Consequently, argentinoids differ from many other euteleost clades, and also from alepocephaliforms, in the presence of a possible compound vertebral centrum that articulates with the parhypural and hypurals 1 and 2 , ventrally.

4. The most anterior uroneural or modified uroneural or stegural with an antero-dorsal membranous outgrowth is interpreted as a euteleostean synapomorphy, but its absence in argentinoids is considered to be secondary by parsimony optimization (Wiley, Johnson, 2010). The element interpreted as the most anterior uroneural in argentinoids and alepocephaliforms is different in both groups. The most anterior uroneural has a complex structure in argentinoids. It was identified as uroneural 1 by Patterson (1970:fig. 37), Greenwood, Rosen (1971:figs. 12, 14), and Fujita (1990:figs. 56-59). According to my studies, the first and enlarged uroneural bearing an expanded membranous outgrowth is an autogenous element lying on the dorsal surface of the compound centrum in juvenile and sub-adult specimens of $\mathrm{Ar}$ gentina sialis and has an overall resemblance to the stegural of salmonids (see Arratia, Schultze, 1992; Grünbaum, Cloutier, 2010) and other euteleosts. However, the antero-lateral base of this element fuses to the dorso-lateral surface of the centrum in larger specimens, resembling a pleurostyle (Fig. 7a, b). Consequently, this element differs from the euteleostean stegural (that is always an autogenous element; Arratia, Schultze, 1992; Grünbaum, Cloutier, 2010), but it also differs from the pleurostyle present in ostariophysans and clupeiforms, except for Denticeps (for information on the pleurostyle see below, section on Analysis of characters). Thus, I term this element a "pseudopleurostyle" to note its different formation than that of the pleurostyle and stegural. Summarizing, there are disagreements concerning the inter- 

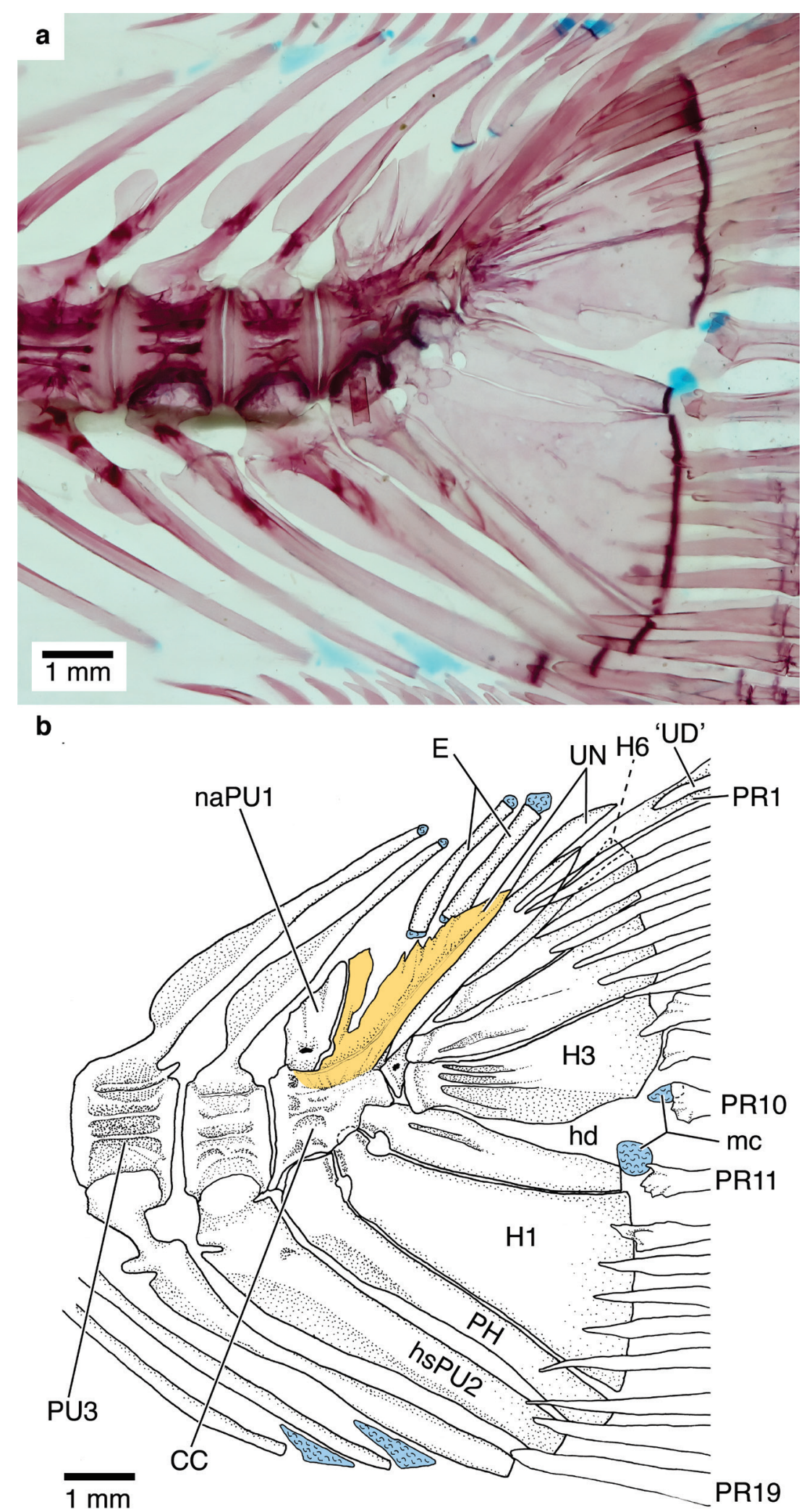

Fig. 7. Caudal skeleton of Argentina sialis (SIO 66-4) in lateral view. a. photograph of specimen of $144.2 \mathrm{~mm}$ standard length; photograph courtesy of C. Quezada-Romegialli; b. interpretative drawing. Note that the posterior hemi-lepidotrichia of principal ray 10 is displaced. The color orange is used to denote a modified uroneural named pseudopleurostyle herein. CC = compound vertebral centrum; $\mathrm{E}=$ epural; $\mathrm{H1}, 3,6=$ hypurals $1,3,6$; hsPU2 = haemal spine of preural centrum 2; naPU1 = neural arch of preural centrum 1; PR1 = 10,11,19 = principal caudal ray 1,10,11,19; PU3 = preural centrum 3; 'UD' = tendon-bone urodermal; $\mathrm{UN}=$ uroneural. 
pretations of alepocephaliforms as argentinoids and also of alepocephaliforms as salmoniforms based on morphological characters.

These older interpretations based on morphological evidence (e.g., Greenwood et al., 1966; Greenwood, Rosen, 1971; Markle, 1976; Lauder, Liem, 1983; Begle, 1992; Johnson, Patterson, 1996; Diogo, 2008; Wiley, Johnson, 2010) have been challenged by molecular evidence, which supports the inclusion of the alepocephaliforms within the Otomorpha (see Fig. 2b, c), specifically as sister to the Ostariophysi (Betancur-R et al., 2017). Lavoué et al. (2008), in turn, found the Alepocephaliformes - Ostariophysi affinity more likely than the Alepocephaliformes - Clupeiformes one, but no definitive conclusion was proposed.

In comparison to the clupeiforms and ostariophysans, the alepocephaliform fossil record is young (Cenozoic) and sparse. It is represented by $\dagger$ Carpathichthys polonicus (see Fig. 8) from the Miocene-Oligocene, about 30 to $23 \mathrm{Ma}$, of Carpathians (Jerzmanska, 1979) and alepocephaliform otoliths of the Mediterranean Basin, Quaternary of Italy (Girone, 2003; Girone et al., 2006).

\section{Material and Methods}

Institutional Abbreviations. Institutional abbreviations where extant material is deposited are listed in Sabaj Perez (2014). Other institutions, which are not listed in Sabaj Perez (2014), are: BGHan = Bundesanstalt für Geowissenschaften und Rohstoffe, Niedersächsisches Landesamt für Bodenforschung, Hannover, Germany. BSPG $=$ Bayerische Staatssammlung für Paläontologie und historische Geologie, München, Germany. DNPM = Departamento Nacional de Producão Mineral, Rio de Janeiro, Brazil. GBA = Geologische Bundesanstalt Wien Abteilung, Palaontologie und Sammlungen, Vienna, Austria. GPIT = Institut und Museum für Geologie und Paläontologie, Tübingen, Germany. GOE = Institut und Museum für Geologie und Paläontologie, Georg-August Universität, Göttingen, Germany. IGM = Geological Institute, National University of Mexico, Mexico City. IVVP = Institute of Vertebrate Palaeontology and Palaeoanthropology, Beijing, China. JM-E = Jura Museum Eichstätt (SOS indicates that the fish was recovered in the Solnhofen Limestone), Eichstätt, Germany. KUVP = Division of Vertebrate
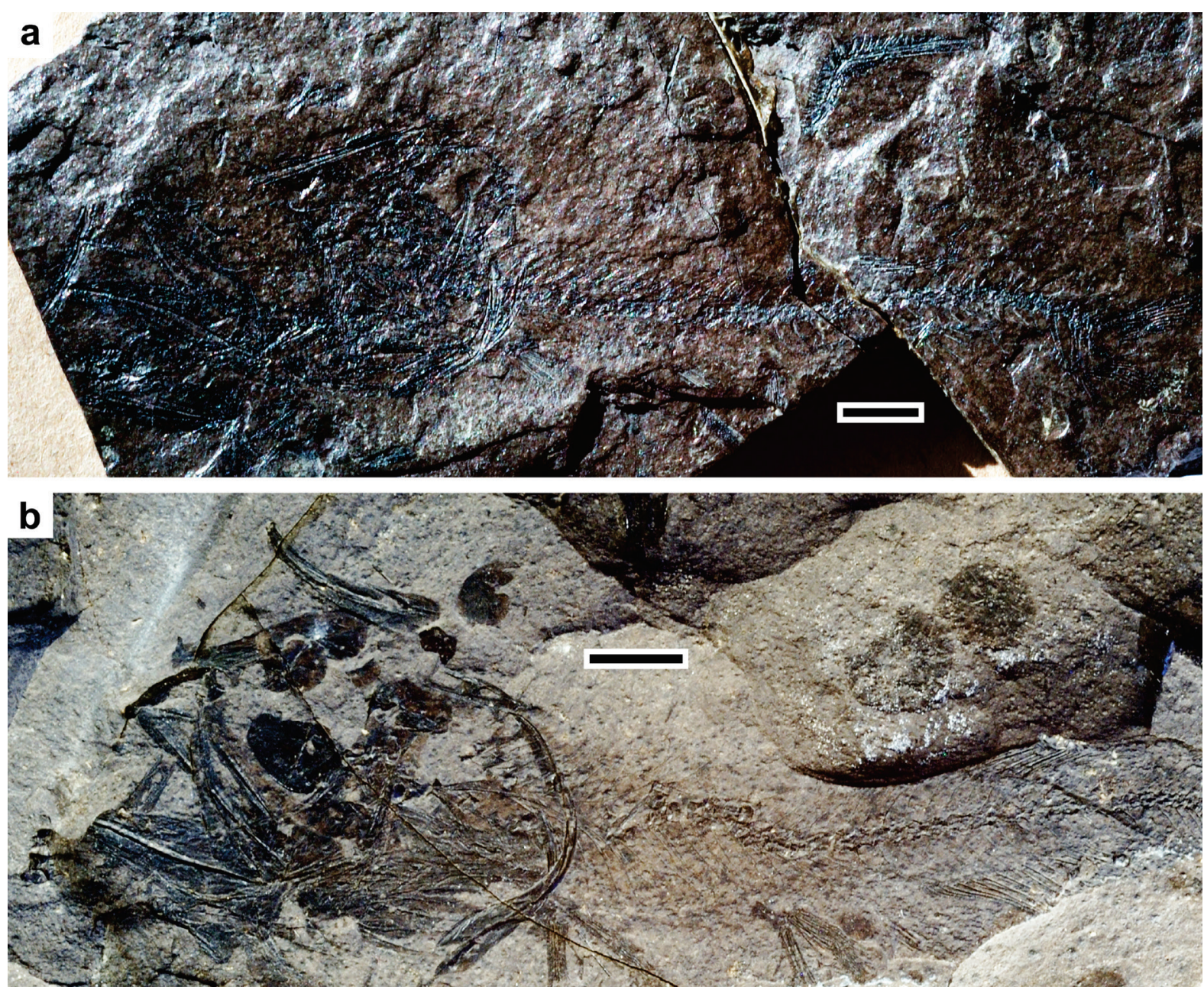

Fig. 8. Fossil otomorph in lateral view: a. Carpathichthys polonicus Jerzmanska, 1979; Miocene-Oligocene, Polish Carpathians, Europe (ZPALWr a/2004, holotype). b. Carpathichthys sp. from the same locality and age (ZPALWr N/6116). Photographs courtesy of Małgorzata Bieńkowska-Wasiluk. 
Paleontology, Natural History Museum, University of Kansas, Lawrence, Kansas. LBUCH = Laboratorio de Biología, Universidad de Chile, Sede Santiago-Sur, Chile. $\mathrm{MB}=\mathrm{Mu}-$ seum of Natural History, Berlin, Germany. MCCM = Science Museum of Castilla-La Mancha, Las Hoyas collection, Cuenca, Spain. Innsb, Department of Geology, University of Innsbruck, Innsbruck, Austria. MCSNB = Museo Civico di Scienze Naturali, Bergamo, Italy. MCSNIO = Civico Museo Insubrico di Storia Naturele, Unduno-Olona, Italy. NHMW = Natural History Museum, Vienna, Austria. SenkM = Senckenberg Museum, Frankfurt-am-Main, Germany. SMNS = Staatliches Museum für Naturkunde, Stuttgart, Germany. UALVP = University of Alberta, Laboratory for Vertebrate Paleontology, Edmonton, Canada. ZPALWr = Department of Palaeozoology, Institute of Environmental Biology, Faculty of Biological Sciences, University of Wrocław, Poland.

Methods. Cleared and stained specimens have been prepared following Dingerkus, Uhler (1977) and Arratia, Schultze (1992). The morphological characters here studied were optimized on the tree of Betancur-R. et al. (2017) using ACCTRAN and DELTRAN (Swofford, Maddison, 1987; Wiley, Lieberman, 2011).

Analysis of characters. The search for potential synapomorphies of Otomorpha was focused on skeletal structures beginning with a revision of characters previously proposed as synapomorphies of clupeiforms plus ostariophysans. The presentation of characters follows the sequence as presented in Lecointre, Nelson (1996).

\section{Results and discussion}

Pleurostyle (Lecointre, Nelson, 1996: character 5; Arratia, 1999: character 141). The term pleurostyle was introduced by Monod (1968) as the paired postero-dorsal processes of preural centrum 1 that occur in all extant clupeoids (= Clupeiformes minus Denticeps) and ostariophysans (Fig. 5). The large uroneural present in Denticeps was interpreted (Grande, 1985) as a possible result of ontogenetic fusion of uroneurals, which is an assumption not supported by primitive otomorphs, i.e., fossil clupeomorphs have independent uroneurals (e.g., Maisey, 1993:fig. 6; Alvarado-Ortega, 2014:fig. 8), with the first one being the largest. None of those uroneurals is fused with preural centrum 1. Unlike the condition present in fossil clupeomorphs, the primitive fossil ostariophysan Tischlingerichthys viohli presents the first uroneural partially fused laterally with the wall of preural centrum 1 , which is fused with ural centra $1+2$ (polyural terminology), forming an elongate compound centrum (Arratia, 1997:fig. 67). Each hypural is associated with its own ural centrum, in a 1:1 relationship, in the polyural terminology (Nybelin, 1977; Schultze, Arratia, 1989, 2013; Arratia, Schultze, 1992; Wiley et al., 2015). In contrast, one ural centrum supports more than one hypural in the diural terminology, e.g., ural centrum 1 supports hypurals 1 and 2, whereas ural centrum 2 supports hypurals 3 and 4 or hypurals 3,4 and 5 .

Ontogenetic studies of clupeiforms and ostariophysans have shown that the so-called processes of the preural centrum 1, or pleurostyle of Monod (1968), may have different origins and topographic relationships. In members of the Clupeoidei, the pleurostyle forms as independent, paired, membranous ossifications of the neural arches of an ural centrum (ural centrum 2 of the polyural terminology) that fuses to the dorsoposterior corner of preural centrum 1 (Fig. 9a; Arratia, 2010:fig. 13c, d; Schultze, Arratia, 2013:figs. 18, 19 , tb. 3). In contrast, in ostariophysans the paired, membranous ossification or pleurostyle (modified neural arch of ural centrum 1 or 2 or 3 of the polyural terminology) may fuse to the dorsoposterior corner of the ural centrum $1+2$ or ural centrum $1+2+3$ (polyural terminology), forming part of the so-called compound centrum (Fig. 9d, e; Arratia, 2010:fig. 13a, b; Schultze, Arratia, 2013:figs. 4, 7b, c, 20, tb. 3). Consequently, the origin of the pleurostyle differs in groups of otomorphs. For instance, the pleurostyle may originate as a transformation of ural neural arch 2 or 3 in Chanos chanos or as a transformation of ural neural arch 1 or 2 in catostomids (Schultze, Arratia, 2013:fig. 7b) and the cyprinid Danio rerio (Schultze, Arratia, 2013:fig. 20). It is still unknown how the pleurostyle of most ostariophysans originates, because it is a common practice in ontogenetic studies of teleosts not to mention the origin and development of vertebral centra (e.g., chordacentra or autocentra) nor the development of the pleurostyle or other uroneurals. In summation, according to available information, the homology of the structure named "pleurostyle" in clupeoids and ostariophysans is unclear.

The pleurostyle is absent in alepocephaliforms, but they have a free structure, unfused with preural centrum 1 or a ural centrum that externally resembles a stegural (Figs. 10, 11 ), which is a modified uroneural characteristic of euteleosts. This is also the condition present in fossil alepocephaliforms (Jerzmanska, 1979:fig. 6). Although the daily ontogenetic formation of the stegural is well documented in salmonids (Arratia, Schultze, 1992; Grünbaum, Cloutier, 2010), a comparison with the stegural-like morphology in alepocephaliforms cannot be provided at this time due to a lack of smaller specimens than those studied here (12.4 $\mathrm{mm}$ SL; see Material studied). Salmonid specimens of the same size already present an elongate uroneural reaching anteriorly to the neural arch of preural centrum 2 . In contrast, in alepocephaliforms of this size, the vertebral centra are not yet formed; see Fig. 10a, b). According to current ontogenetic information concerning the different origins and relationships of the pleurostyle in clupeoids and ostariophysans and the absence of a pleurostyle in Denticeps and alepocephaliforms, this character does not stand as a synapomorphy of Otomorpha.

Fusion of hypural 2 with first ural centrum (Lecointre, Nelson, 1996: character 6). The base of hypural 2 fused to ural centrum 1 (= diural terminology) or ural centrum 2 

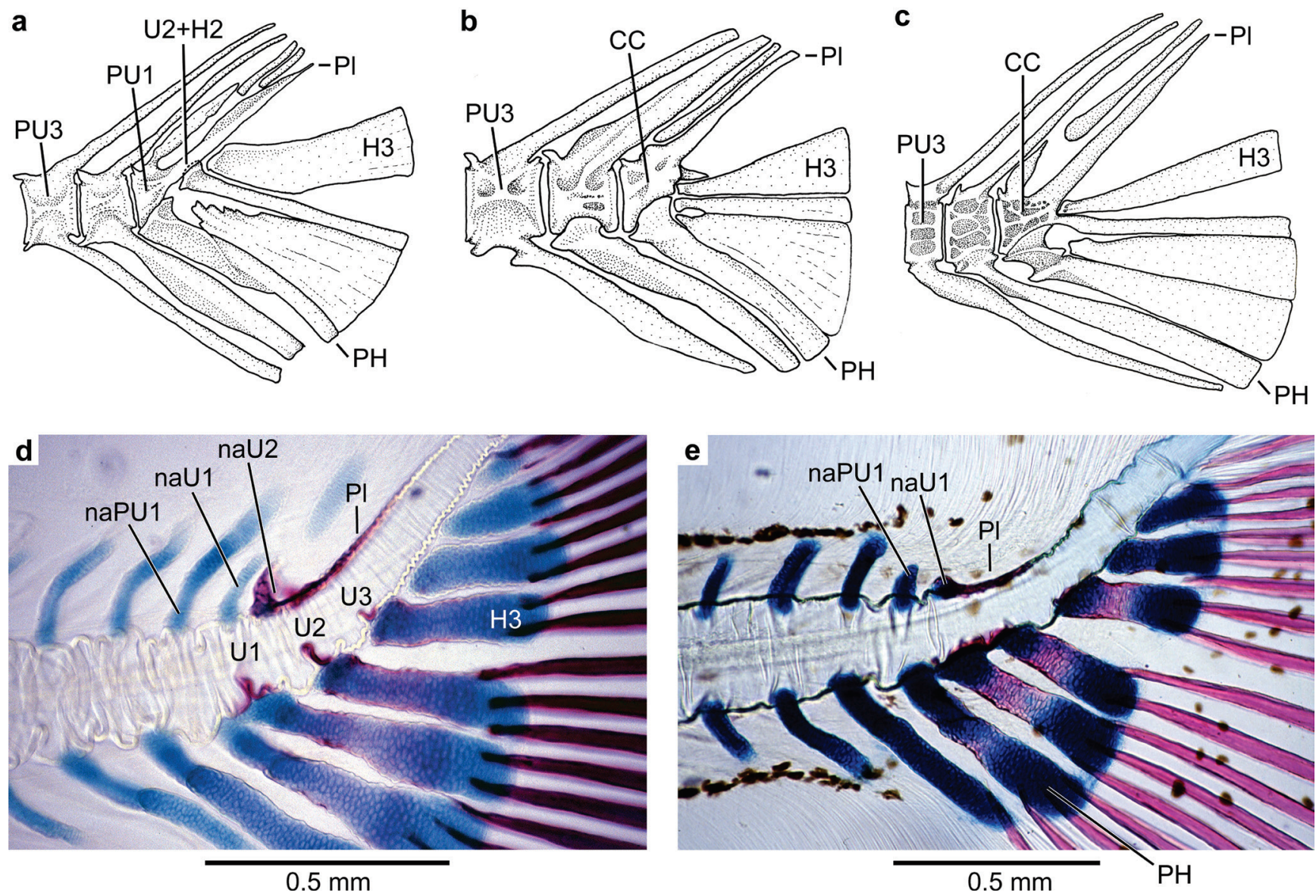

Fig. 9. Diagrammatic caudal skeletons in lateral view illustrating the pleurostyle, its relationships (a-c) and early development (d, e). a. clupeoid; b. gonorynchiform; c. cypriniform; d. part of caudal skeleton in lateral view of the cypriniform Catostomus commersoni, $13.4 \mathrm{~mm}$ SL (KU:KUI 38655); e. part of caudal skeleton in lateral view of the cypriniform Luxilus zonatus, $8.7 \mathrm{~mm}$ SL (KUI uncat.). $\mathrm{CC}=$ terminal caudal compound centrum; H3 = hypural 3; naPU1 = neural arch preural centrum 1; naU1, naU2 = neural arch of ural centrum 1, of ural centrum 2 [of the polyural terminology; ural centrum 1 of the diural terminology]; $\mathrm{PH}=$ parhypural; $\mathrm{Pl}=$ plurostyle; $\mathrm{PU} 1=\mathrm{PU} 3=$ preural centrum 1,$3 ; \mathrm{U} 2+\mathrm{H} 2$ = ural centrum $2+$ hypural 2 [= ural centrum 2 of polyural terminology; ural centrum 1 of diural terminology]; U1-3 = ural chordacentrum 1, 2, 3 [of the polyural terminology, each associated with its correspondent hypural].

(of the polyural terminology) was proposed by Lecointre, Nelson (1996) as a possible synapomorphy of the clade formed by extant clupeomorphs and ostariophysans. The authors remarked that this fusion is lacking in gonorynchiforms, such as $\uparrow$ Rubiesichthys, $\dagger$ Tharrhias, and the extant Chanos. It is also lacking in other extant gonorynchiforms (Grande, Arratia, 2010:fig. 2.12). Hypural 2 is also unfused in the Late Jurassic ostariophysan incertae sedis $\dagger$ Tischlingerichthys (Arratia, 1997:fig. 67).

Studies of the caudal skeleton based on ontogenetic series of clupeomorphs and ostariophysans have shown that early in ontogeny the base of hypural 2 fuses to ural centrum 2 (polyural terminology) in clupeiforms, such as Denticeps and clupeoids (which are missing ural centrum 1 in front of the base of hypural 1 early in ontogeny; Arratia, 2010:fig. 13c, d; Schultze, Arratia, 2013:figs. 7c, 18, 19), as well as in ostariophysans (Arratia, 2010:fig. 13b; Schultze, Arratia, 2013:figs. 4, 18-20), but not in the gonorynchiform Chanos chanos (Fig. 9b), which has a free hypural 2 from early ontogeny. In siluriforms, at least the bases of hypurals 1 and 2 are fused to the so-called compound centrum present in most primitive forms, such as in Diplomystes and Nematogenys, but further fusions including other hypurals are observed in different catfish lineages (Lundberg, Baskin, 1969; Arratia, 1982), whereas in gymmnotiforms, the caudal skeleton is highly modified and reduced (de Santana et al., 2013).

Hypural 2 and the remaining hypurals are autogenous (Figs. 10,11) in alepocephaliforms from early in ontogeny. Alepocephaliforms, contrary to clupeiforms and ostariophysans, present a continuous haemal cartilage (Fig. 10b-d) that extends from the haemal arch of preural centrum 5 or 6 posteriorly, reaching the base of hypural 3 in the smallest specimens studied. The haemal cartilage separates the haemal arch from the ventro-lateral wall of the notochord or the centra, depending on the growth stage. Considering the distribution of this character in a phylogenetic hypothesis either 

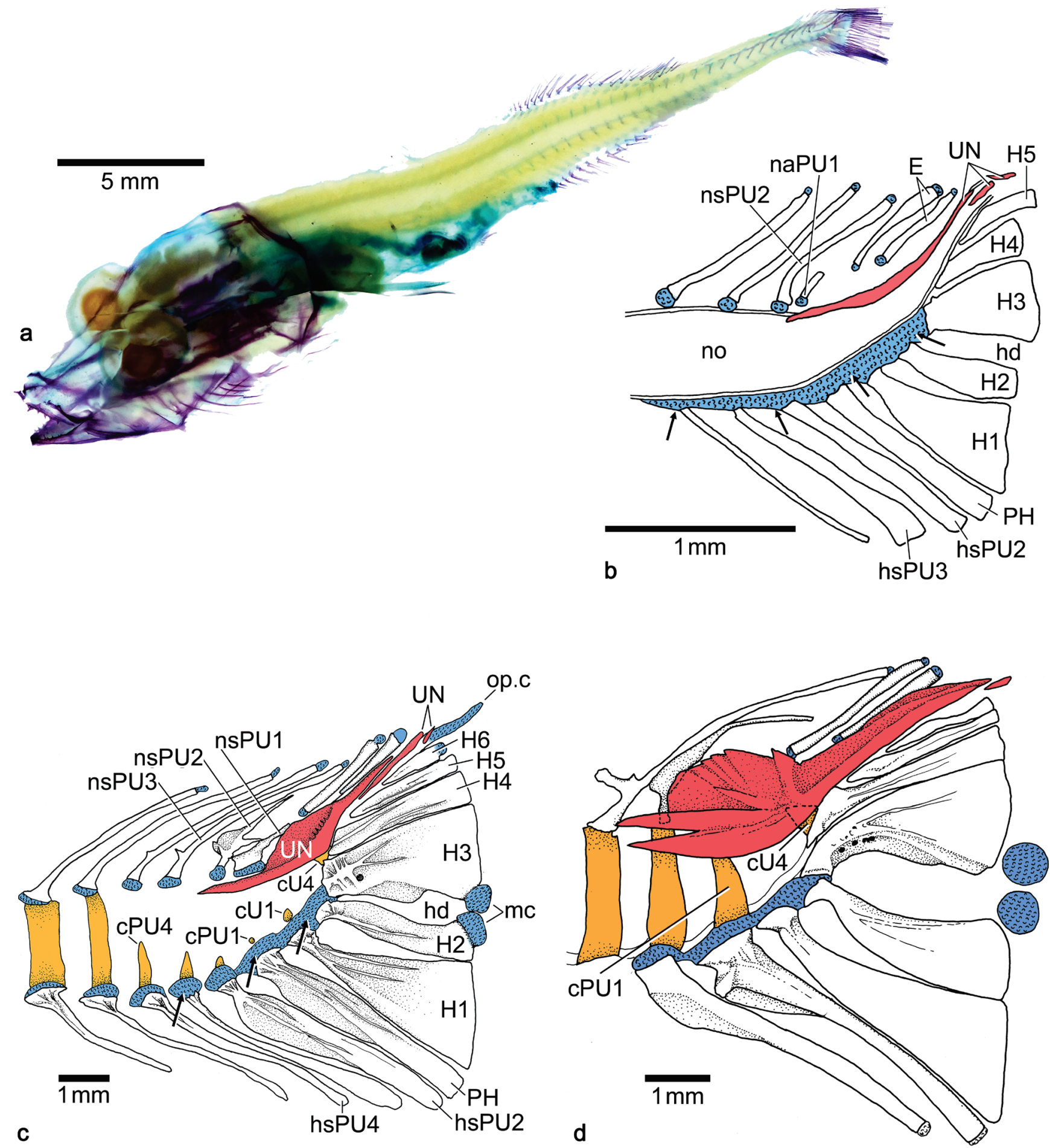

Fig. 10. Ontogenetic development of the caudal skeleton in alepocephaliforms. a. larva of Talismania bifurcata of $28.18 \mathrm{~mm}$ standard length (KU:KUI 41395) illustrating a functional notochord and formation of neural and haemal arches and spines developing from caudad to rostrad direction; $\mathbf{b}$. detail of the caudal skeleton of specimen illustrated in a; note the unusual extension of the haemal cartilage; c. larvae of $68 \mathrm{~mm}$ standard length; note the marked differences in the development of chordacentra; small arrows point to the haemal cartilage d. Searsia koefoedi; specimen of $126 \mathrm{~mm}$ standard length; note the development of the first uroneural or stegural-like element and the lack of chordacentra in front of hypurals 1 and 2. Photograph courtesy of C. Quezada-Romegialli. cPU1 = preural chordacentrum 1; cU1, $4=$ ural chordacentrum 1, 4 [polyural terminology; ural centrum 1, 2 of diural terminology]; E = epural; h1-6 = hypural 1-6; hd = hypural diastema; hsPU2, hsPU3, hsPU4 $=$ haemal spine of preural centrum 2, 3, 4; mc = median caudal cartilages; naPU1 = neural arch of preural centrum $1 ;$ ns PU2, nsPU3 = neural spine of preural centrum 2, 3; no = notochord; op.c $=$ ophistural cartilage; $\mathrm{PH}=$ parhypural; $\mathrm{UN}=$ uroneurals. 


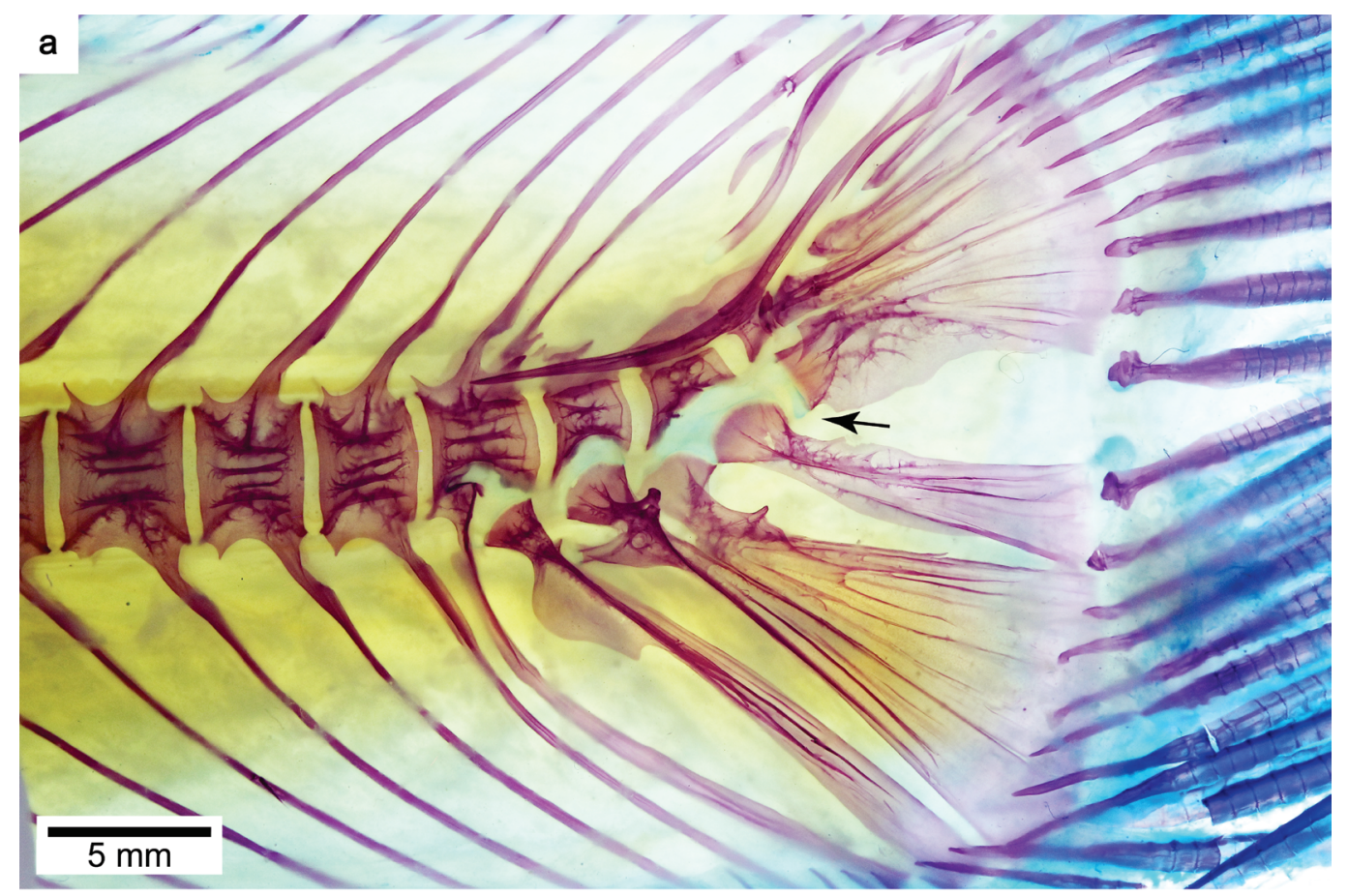

b

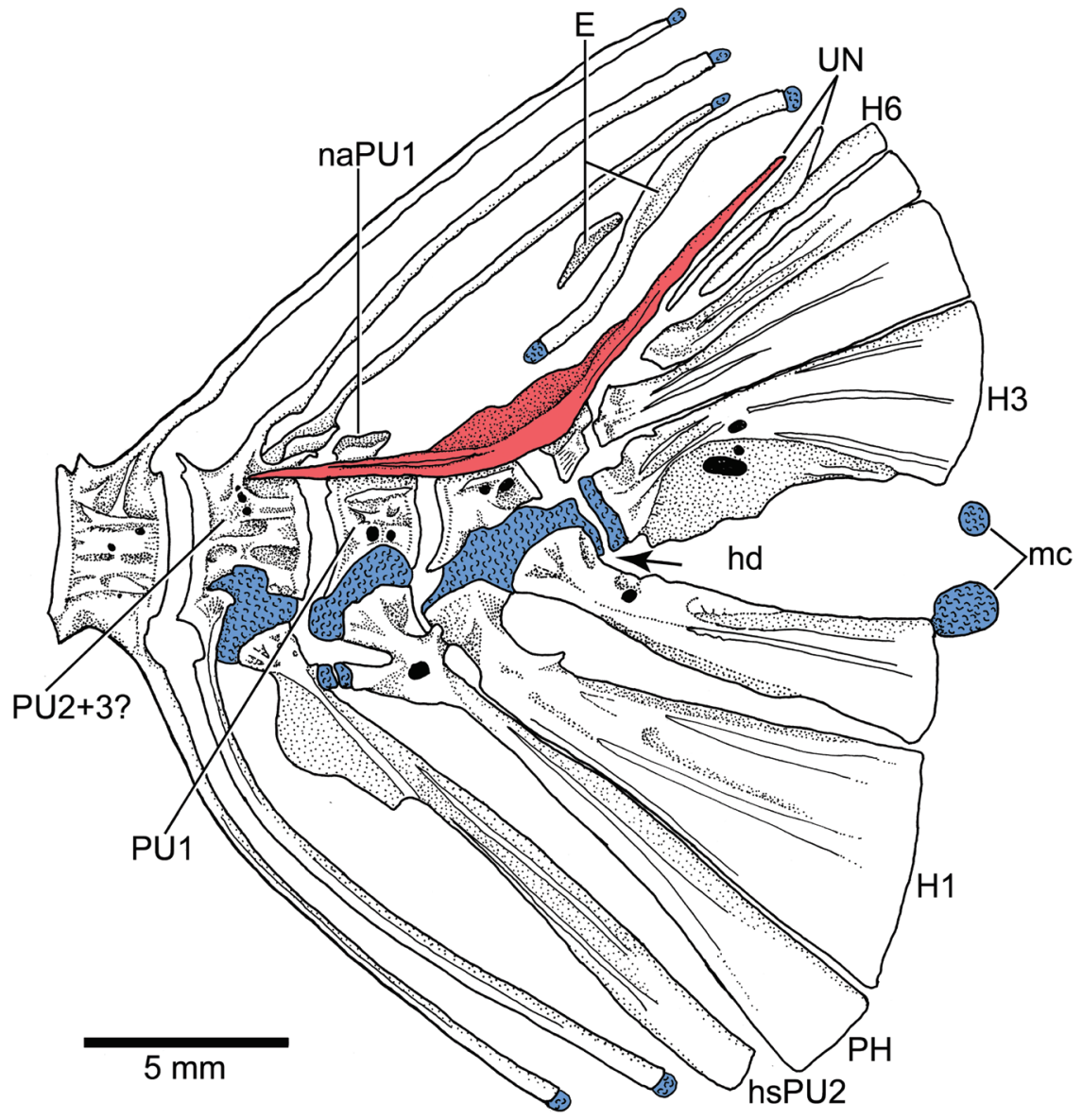

Fig. 11. Caudal skeleton of Alepocephalus tenebrosus (UW 042217 \#4). a. photograph of specimen of 363 mm standard length; photograph courtesy of C. Quezada-Romegialli; b. interpretative drawing. Note the articulation between the proximal region of hypural 3 and the haemal cartilage (arrow) uniting hypurals 1 and $2 . \mathrm{E}=$ epural; H1, 3, $6=$ hypural 1, 3, 6; hd = hypural diastema; hsPU2 = haemal spine of preural centrum $2 ; \mathrm{mc}=$ median caudal cartilages; naPU1 = neural arch of preural centrum 1; no = notochord; $\mathrm{PH}=$ parhypural; $\mathrm{UN}=$ uroneurals; the small third one is not shown. 
morphological (Figs. 2, 3) or molecular (Fig. 2), the lack of fusion between hypural 2 and ural centrum 2 (polyural terminology) in alepocephaliforms and most gonorynchifor$\mathrm{ms}$ represents the plesiomorphic condition in teleosts (that is interpreted as secondary loss at this phylogenetic level); whereas their fusion in clupeiforms, a few gonorynchiforms, and otophysans is a unique feature among teleosts that could be interpreted as an otomorph synapomorphy (see Fig. 12, black star). However, ACCTRAN and DELTRAN analyses of this character show this to be ambiguous as a synapomorphy of Otomorpha, thus no conclusion can be reached as to its absence in Alepocephaliformes and most gonorynchiforms relative to other otomorphs.

Fusion of extrascapular and parietal bones (Lecointre, Nelson, 1996: character 7; Arratia, 1999: character 32). The otic canal passes near the lateral margin of the (lateral) extrascapula in teleosts where the bone is present. The canal gives off a branch, the supratemporal canal or supratemporal commissure or extrascapular commissure, that extends medially, ending in the extrascapula(e) or on the parietals and supra- occipital, uniting both left and right extrascapular series. It has been assumed that when the supratemporal canal passes through parietal bones, a medial extrascapula has fused with the parietal lying below, but this assumption does not explain the canal passing above or in a groove of the supraoccipital.

A supratemporal canal or commissure primitively passing through parietals and the supraoccipital is considered a synapomorphy of clupeomorphs (e.g., Grande, 1985) including Denticeps (e.g., Di Dario, de Pinna, 2006). The presence of a medial extrascapula that may fuse or ankylose late in ontogeny with the parietal bone lying below is observed in the ontogenetic series of Chanos chanos (Fig. 13a, b) and other gonorynchiforms, with the exception of the highly modified kneerids, which lack parietal bones, even in their fossil representatives (Davis et al., 2013). A similar pattern of fusion is observed in other extant ostariophysans (Fig. 13c, d; Arratia, Huaquín, 1995:fig. 3).

Lecointre, Nelson (1996:p. 202) first proposed that a fusion of a medial extrascapula and the parietal bone is a synapomorphy of ostariophysans and clupeomorphs. Later, Arratia (1999:p. 325) described the character for her Os-

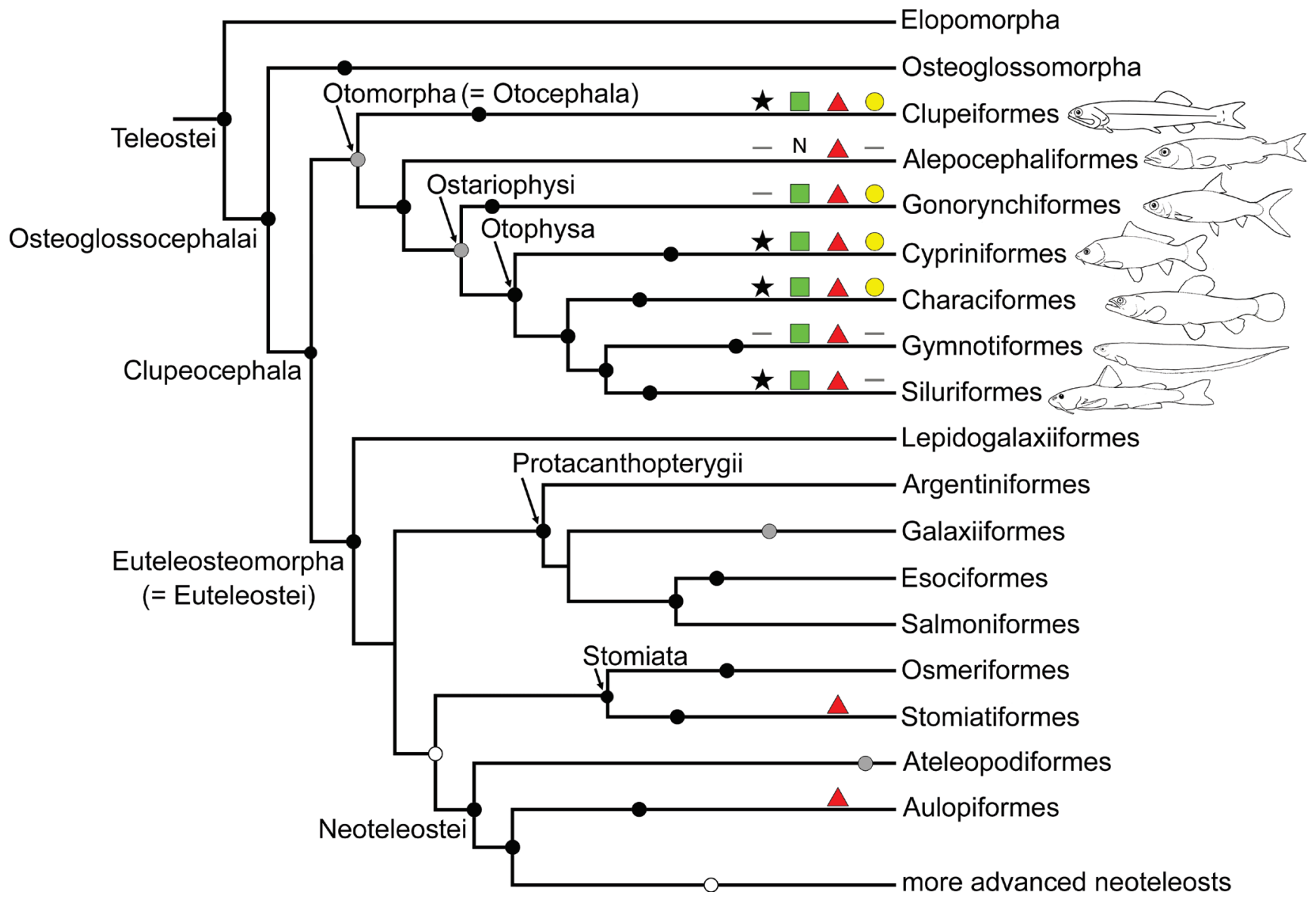

Fig. 12. Abbreviated phylogenetic hypothesis of teleosts (modified from Betancur-R. et al., 2017) with distribution of certain character states discussed in the text. Yellow circle = fusion or ankylosis between medial extrascapular and parietal bones; red triangle $=$ vertebrae anterior to preural centrum 2 with haemal arches and centra fused in juvenile-adult individuals; green square $=$ silvery areas associated with gas bladder; black star $=$ hypural 2 fused with ural centrum 2 [of the polyural terminology; ural centrum 1 of the diural terminology]. $\mathrm{N}=$ non applicable. 

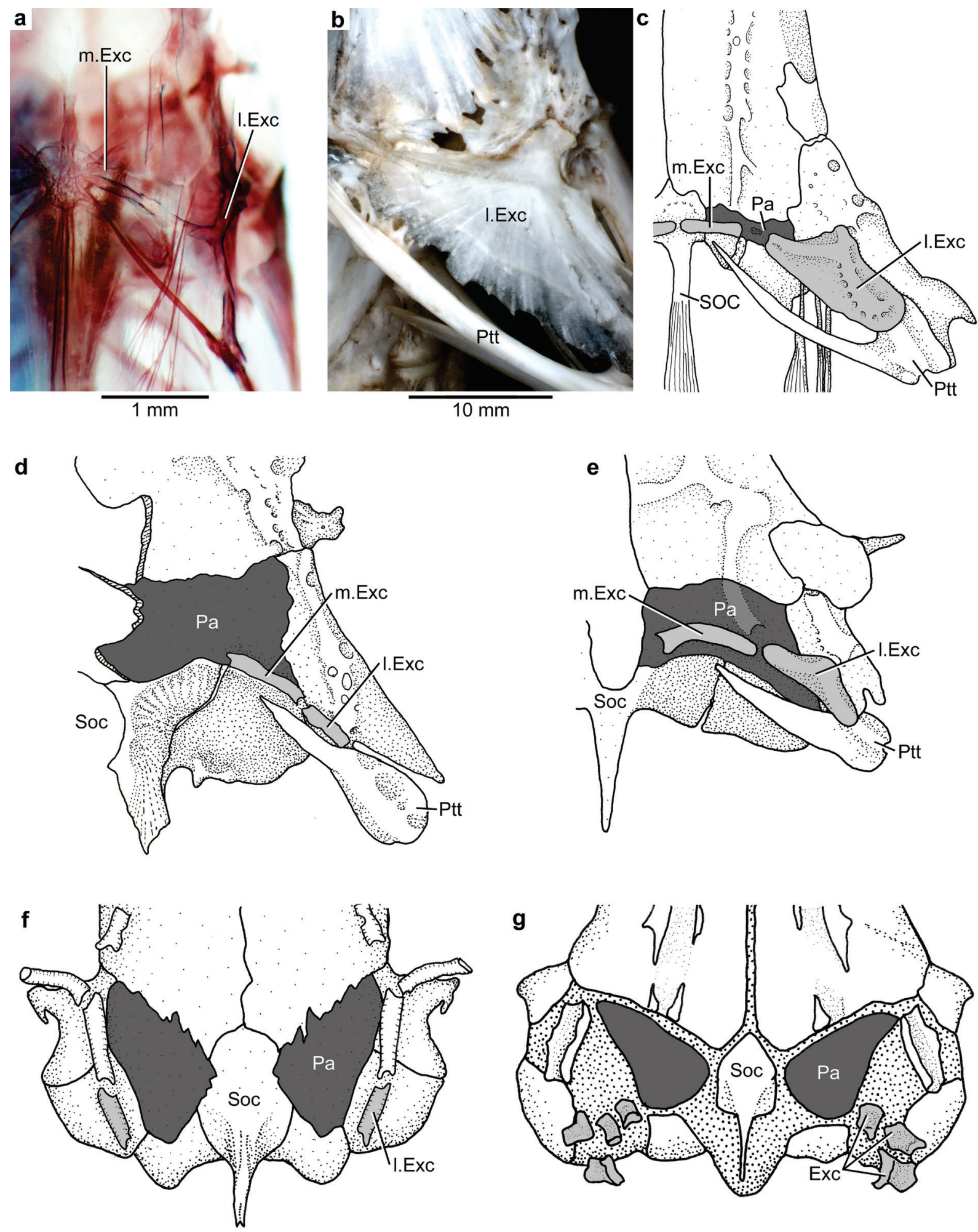

Fig. 13. Posterior cranial region of otomorphs illustrating the relationships of the extrascapular and parietal bones and sensory canals. a. gonorynchiform Chanos chanos of $45 \mathrm{~mm}$ standard length; KUI 38796; b. Chanos chanos of $370 \mathrm{~mm}$ standard length; KUI 40935; c. diagrammatic drawing of Chanos chanos; d. diagrammatic drawing of the cypriniform Opsariichthys bidens (CAS 15639); e. diagrammatic drawing of the characiform Xenocharax spilurus (CAS 32512); f. diagrammatic drawing of the alepocephaliforms Leptoderma sp.; g. diagrammatic drawing of the alepocephaliform Searsia koefoedi. c-e, modified from Arratia, Huaquín, 1995 and f, g, modified from Greenwood, Rosen, 1971. Exc = ossicle-like extrascapular bones; 1 . Exc $=$ lateral extrascapula; $\mathrm{m}$. Exc $=$ medial extrascapula; $\mathrm{Pa}=$ parietal bone [of traditional terminology]; Ptt $=$ posttemporal; Soc $=$ supraoccipital. 
tarioclupeomorpha (= Otocephala) as "clupeocephalans in which primitively there is an ankylosis or fusion between the medial extrascapula and parietal alone or parietal and supraoccipital".

Alepocephaliforms do not present this character. An ossicle-like lateral extrascapula is present in some genera (e.g., Leptoderma sp. and Searsioides; Fig. 13e) and a medial ossicle-like extrascapula is absent so that a supratemporal canal is absent or very short. Other alepocephaliforms have an irregular series of two or more small ossicle-like extrascapular bones, but a supratemporal canal passing on the parietals or parietals plus supraoccipital is not present (e.g., Paraholtbyrnia, Pellisolus, Mirorictus, and Searsia; Fig. 13f; see also Greenwood, Rosen, 1971).

Primitively, both the clupeiforms and ostariophysans are unique among teleosts in possessing a fusion or ankylosis of the medial extrascapula with the parietal bone so that the supratemporal canal passes through both bones. This condition is lacking in alepocephaliforms, which have one or multiple ossicle-like free extrascapulars and no medial extension of the supratemporal canal. Absence in alepocephaliforms and most advanced ostariophysans (Fig. 12, yellow circle) is secondary by parsimony optimization. Thus, following this interpretation, this character can be interpreted as a synapomorphy of otomorphs.

Fusion of hemal arches and centra anterior to preural centrum 2 (Lecointre, Nelson, 1996: character 8). The original character description indicated a fusion between haemal spines and centra. However, the centra are the ones fused to their respective arches during ontogeny.

This character was suggested first as an ostariophysan synapomorphy by Fink, Fink (1981, 1996), who also mentioned that the fusion is present in the caudal region of all clupeiforms, suggesting a possible relationship among the groups. However, clupeiforms lack an adipose fin and nuptial tubercles, which are features that are present in ostariophysans that link them to euteleosts, a view favored by Fink, Fink (1981).

Lecointre, Nelson (1996:p. 202) pointed out that this feature is consistently present in all extant clupeomorphs and ostariophysans (see also Monod, 1968; Fujita, 1990) and in their fossil representatives (Arratia, pers. observations). However, and following Fujita's (1990) caudal skeleton survey, Lecointre, Nelson (1996) stated that this feature might be also present in some euteleostean subgroups of various phylogenetic positions, but not in all members of each subgroup, e.g., in Umbra among esociforms and in Bathylagus among osmeriforms. Some species with all haemal arches anterior to preural centrum 2 fused to their centra are found in some Stomiatiformes, Myctophiformes, and a few more advanced neoteleosts (e.g., Aulopiformes). Those occurrences outside the otocephalans or ostarioclupeomorphs make this feature homoplastic.

Juvenile and adult alepocephaliforms present all haemal arches anterior to preural centrum 2 fused to their centra
(Fig. 11). In early ontogenetic stages (Fig. 10), the haemal arches anterior to preural centrum 2 are unfused with their respective centra represented by chordacentra. Autocentra of the caudal region begin to form in the juvenile so that the fusion between dorsal and ventral arcocentra to their respective autocentrum is comparatively later than in other otomorphs. Thus, clupeiforms, alepocephaliforms, and ostariophysan share the presence of fused arches and centra anterior to preural centrum 2 in juvenile-adult growth stages. According to the distribution of this character in the phylogenetic hypothesis shown in Fig. 12 (red triangle), this feature stands as a synapomorphy of Otomorpha, including the alepocephaliforms. Its erratic occurrence in some Stomiatiformes and Myctophiformes can be interpreted as independently acquired (This character has not been represented in Fig. 12 where it occurs only in one genus, e.g., Umbra within Esociformes).

Bases of hypurals 1 and 2 not joined by cartilage at any growth stage (Arratia 1999: character 135). Arratia's (1999; Fig. 3 herein) phylogenetic hypothesis included fossil and extant teleosts, and because of this and the fact that in primitive fossil clupeiforms (e.g., †Santanaclupea) and fossil ostariophysans (e.g., $\dagger$ Tischlingerichthys) the bases of hypurals 1 and 2 are not joined by cartilage, Arratia (1999:p. 325) specifically wrote that this feature stands as a synapomorphy at the primitive level of the Ostarioclupeomorpha (=Otocephala). Most extant clupeiforms and ostariophysans may show cartilage at the base of one hypural, or at the base of hypural 1 and arch of the parhypural, or both are fused to the autocentrum from early stages of development. In adult clupeiforms and ostariophysans, the bases of hypurals 1 and 2 are not connected by cartilage, a unique feature among teleosts (see also Monod, 1968; Fujita, 1990).

The poorly known caudal skeleton of the fossil alepocephaliform †Carphathichthys polonicus (Jerzmanska, 1979:fig. 6) shows spaces between the bases of hypurals 1 and 2 and the ventral margins of the centra, that may indicate the presence of cartilage during life as the condition present in extant alepocephaliforms (see Figs. 10, 11). However, I have not been able to examine the fossil material, only had access to photographs. Extant alepocephaliforms are unique in the presence of a long tube-like haemal cartilage surrounding the caudal blood vessels that extends from the haemal arches of preural centrum 4 or 5 to the base of hypural 3 in juveniles and is restricted to the bases of hypurals 1-3 in adults. The posterior part of the haemal cartilage produces an articular surface for the base of hypural 3 (see Figs. 10, 11), another unique character of this group among otomorphs. A similar articulation seems to be present as a convergence in some stomiatiforms and myctophiforms (see Fujita, 1990:figs. 76, 111).

Considering the new information on alepocephaliforms and the fact that I have not been able to examine their fossil representatives, I prefer to postpone further suggestions or conclusions about this character. 
Silvery area associated with gas bladder. The anterior chamber of the gas bladder partly to completely covered by a silvery peritoneal tunic was proposed as a possible synapomorphy of Clupeomorpha plus Ostariophysi by Wiley, Johnson (2010), following Fink, Fink (1996), who listed it as an ostariophysan synapomorphy, but indicated that a similar condition was also present in some clupeomorphs and therefore might be synapomorphic for the clade (that was given a name in another chapter of the same volume: Johnson, Patterson, 1996) containing the two groups. A gas bladder is characteristically absent in alepocephaliforms among teleosts (Berg, 1937; Johnson, Patterson, 1996; Wiley, Johnson, 2010); this absence makes the character ambiguous, because it is impossible to know if the structure primitively had a shiny peritoneal tunic in the group or not. Another hypothesis is that this absence in alepocephaliforms (Fig. 12, green square) represents a secondary loss among otomorphs, and consequently, this character stands as a synapomorphy of otomorphs, a hypothesis that is supported by parsimony optimization.

Additional cartilage attached to ceratobranchial 5. The finding of an additional cartilage attached to ceratobranchial 5 (Nelson, 1967) was important for separating fishes with a branchial pouch. The additional cartilage is characteristic of the crumenal organ present in alepocephalids and argentinoids (Greenwood, Rosen, 1971; Johnson, Patterson, 1996), whereas this cartilage is absent in the epibranchial organ found in gonorynchiforms with different cartilages (Fig.
$14 \mathrm{~b}, \mathrm{c})$. Thus, the finding of a vestigial additional cartilage attached to ceratobranchial 5 (Fig. 14a) in the clupeomorph Denticeps clupeoides (de Pinna, Di Dario, 2010) is important because it "provides circumstantial support for a possible relationship between Otocephala and argentinoid and may indicate a vestigial remnant of an epibranchial organ in Denticeps" (de Pinna, Di Dario, 2010:p. 251). It may be argued that this new information may provide a circumstantial support of a vestigial crumenal organ in Denticeps more than an epibranchial organ, because the cartilages in gonorynchiforms, as illustrated in Figure 14b, c are not the same as the vestigial cartilage associated with ceratobranchial 5 in Denticeps. This character is also present outside the clade Otomorpha in Argentiniformes.

A survey of other osteological structures, cephalic sensory canals, and pit lines did not provide further support for the monophyly of otomorphs.

\section{Conclusions}

Considering that without exception recently published molecular studies have indicated that the alepocephaliforms, clupeiforms, and ostariophysans form a monophyletic assemblage, I have revisited this phylogenetic hypothesis from a morphological point of view. This was based on the fact that all synapomorphies previously cited for otocephalans or ostarioclupeomorphs are mainly osteological (Lecointre, Nelson, 1996; Arratia, 1997, 1999), except one (Fink, Fink,
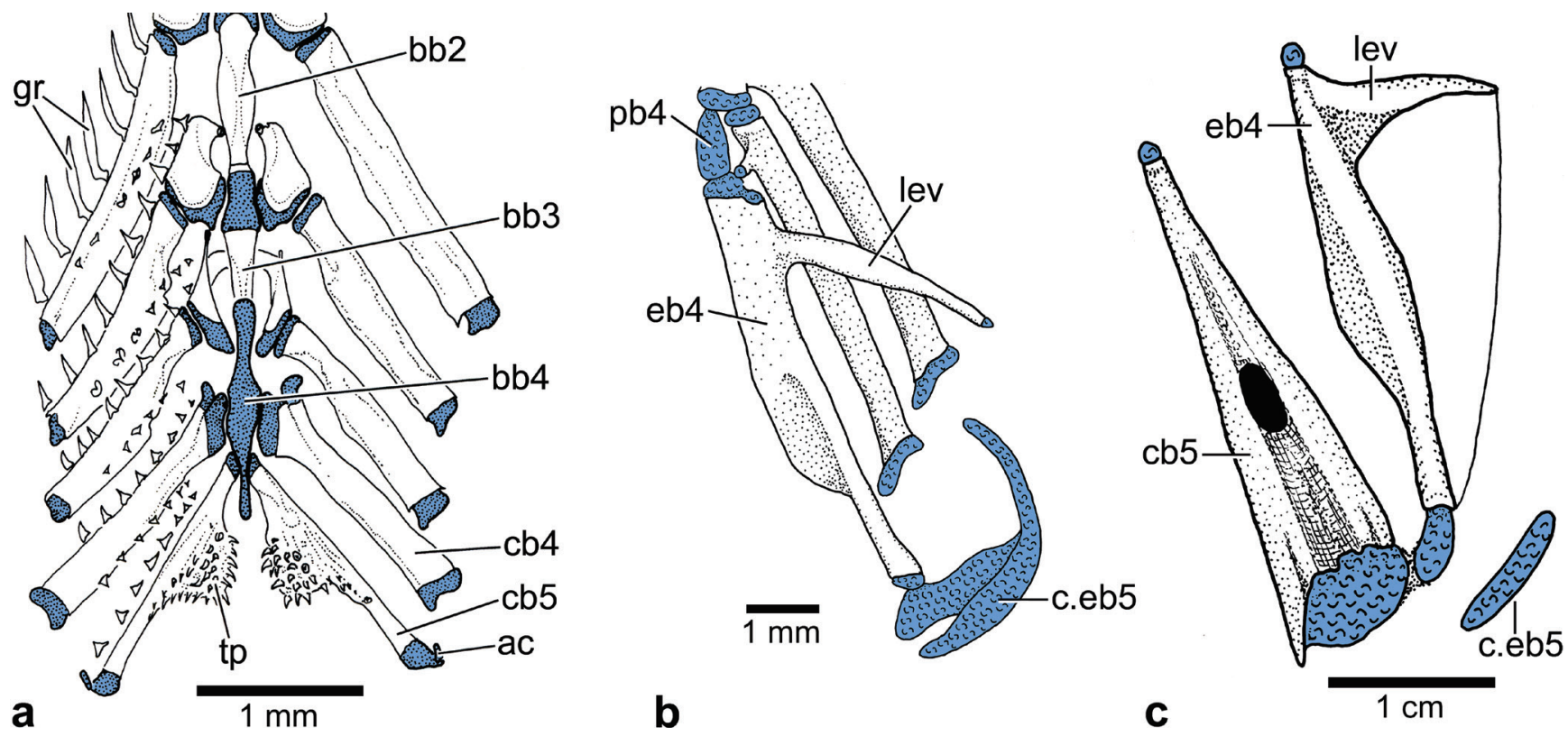

Fig. 14. Branchial arches and cartilages. a. Denticeps clupeoides illustrating a vestigial cartilage associated with ceratogranchial 5 (modified from de Pinna, Di Dario, 2010); b. epibranchials 4 and 5 in left lateral view illustrating the cartilaginous epibranchial 5 in a young specimen of Chanos chanos (modified from Johnson, Patterson, 1997); c. ceratobranchial 5 and cartilaginous epibranchial 5 in dorsal view in a large specimen of Chanos chanos of 490 mm SL (KU:KUI 40365). Arrow point to an elastic fiber membrane supporting branchial lamellae. ac = additional cartilage; bb2-4 = basibranchials 2-4; cb4,5 $=$ ceratobranchials 4,5; c.eb5, cartilaginous epibranchial 5eb4 = epibranchial 4gr = gill rakers; lev = levator process; pb4 = pharyngobranchial $4 ; \mathrm{tp}=$ tooth plate. Note the reduction in size of the cartilaginous epibranchial 5 in Chanos chanos. 
1996). Thus, a study of alepocephaliform osteology, sensory canals and pit lines was executed for comparisons among the three groups. Among otomorphs, alepocephaliforms are characterized by the loss of several structures and at least four of them concern characters previously proposed for otocephalans. The results show that the potential characters supporting the monophyly of Otomorpha are homoplastic:

1. The fusion of hemal arches and centra anterior to preural centrum 2 in juvenile and adult individuals is a synapomorphy of Otomorpha (Fig. 12, red triangle), although this fusion also occurs in a few unrelated euteleosts (e.g., stomiatiforms and myctophiforms). Under current knowledge, this is an unambiguous synapomorphy supporting the clade.

2. A fusion of ural centrum 2 [polyural terminology] with the base of hypural 2 is present in clupeomorphs, cypriniforms, characiforms, and siluriforms. The highly modified caudal skeleton of gymnotiforms may include reduction and fusion of all its endoskeletal structures. Most gonorynchiforms have unfused elements, as do alepocephaliforms. The fusion between hypural 2 and ural centrum 2 is unique to these fishes among the crown Teleostei (Fig. 12, black stars) and its absence among primitive otomorphs (alepocephaliforms and most gonorynchiforms) is ambiguous.

3 . The (medial) extrascapula and parietal bone are fused so that the supratemporal canal extends into the medial extrascapula or in both the medial extrascapula and supraoccipital. This character is not present in alepocephaliforms due to the absence of well-defined extrascapular bones and a supratemporal canal (Fig. 13f, g). According to the distribution of this character among teleosts, this loss in alepocephalifor$\mathrm{ms}$ (Fig. 12, yellow circle) is best interpreted as a secondary loss, and consequently, the character may still be interpreted as an otomorph synapomorphy.

4. A silvery area associated with the gas bladder is present in clupeomorphs and ostariophysans (Fink, Fink, 1996; Wiley, Johnson, 2010) among teleosts. In contrast, alepocephaliforms do not share this character, because they do not have a gas bladder, which is considered a synapomorphy of the group. According to the occurrence of this character in otomorphs (Fig. 12, green square) among teleosts, this loss in alepocephaliforms is interpreted as a secondary loss and the character still can be considered an otomorph synapomorphy.

Consequently, all characters proposed as synapomorphies of Otomorpha are homoplastic, which is a common condition of many characters supporting different teleostean nodes among the crown Teleostei. This is especially the case in phylogenetic studies including large numbers of taxa where losses or reversals at different levels change interpretations of characters, e.g., from those previously interpreted as uniquely derived to homoplastic.

A survey of the literature reveals that most (or all?) phylogenetic higher-level hypotheses of teleostean intrarelationships are heavily based on osteological characters, including sensory canals. Despite the great efforts spent by teleostean researchers to understand osteological characters, numerous cases remain unclear, especially those concerning interpretations of homologous characters of the caudal fin. See above for information concerning the so-called uroneural 1 in argentinoids, alepocephaliforms, and ostariophysans (Figs. 7, 9, 10, 11) or the so-called compound centrum in some argentinoids, clupeomorphs, ostariophysans (Figs. 7, 9). Although knowledge on branchial arches has increased during recent years, more effort should be spent on investigations concerning branchial arches, and their cartilages and muscles, especially within the large diversity of otomorphs and closely related clades. In the particular case of otomorphs, it is suggested that future researchers explore other anatomical structures outside osteology such as muscles and ligaments, and soft anatomical complexes, such as the nervous, circulatory, or digestive systems.

Finally, I would like to call the attention to the fact that among otomorphs there are three main groups characterized by numerous autapomorphies: Denticipitidae, Alepocephaliformes, and Gymnotiformes. The three taxa share being the youngest clades in Otomorpha, which has a long fossil history of at least $145 \mathrm{Ma}$. Among otomorphs, the youngest ones seem to be the gymnotiforms, with their oldest record being from the upper Miocene (about $23 \mathrm{Ma}$; Gayet, Meunier, 1991) and the alepocephaliforms, with the oldest fossil record of about 30-23 Ma. Has the late origin of these taxa some bearing on their uniqueness that poses difficulties in the interpretation of characters?

Material Studied. In addition to the otomorph species, the material listed below also includes other teleosts used in comparisons. The specimens are listed following a taxonomic arrangement and ordered alphabetically within each taxon. Extinct taxa are identified with the sign ' $\uparrow$ '; cl\&st = cleared and double stained specimens for cartilage and bone; skl = dry skeleton.

\section{Neopterygi; Teleosteomorpha}

Teleostei (apomorphy-based group)

$\uparrow$ Pholidophoriformes. $†$ Pholidophoridae: $\uparrow$ Annaichthys pontegiurinensis: MCSNB 11282a, b, c (holotype); MCSNB 11282d; and MCSNB 11283. $\uparrow$ Knerichthys bronni: GBA 1866/004/0009 (holotype). Innsb. 6b, 6c; GBA 2006/096/0024); GBA 2006/098/0150; and GBA 2006/087/0055. $\dagger$ Lombardichthys gervasuttii (= $\dagger$ Pholidophorus gervasuttii): MCSNB 4723a-c (holotype); MCSNB 3462d; MCSNB 4300a-c; MCSNB 4301a-d; MCSNB 4302a-b; MCSNB 4303a-d; MCSNB 4304a-d; MCSNB 4305; MCSNB 4306a-b (no 3406a-b in Arratia, 2013); MCSNB 4308; MCSNB 4309; MCSNB 4310a-g; MCSNB 4311; MCSNB 4312; MCSNB 4313; MCSNB 4317a-c; MCSNB 4318a; MCSNB 4329a-b; MCSNB 4330; MCSNB 4334; MCSNB 4340; MCSNB 4345a-b; MCSNB 4346a-d; MCSNB 4416; MCSNB 4418; MCNB 4425; MCSNB 4438; MCSNB 4453; MCSNB 4455; MCSNB 4469a-b; MCSNB 4470a-b; MCSNB 4473; MCSNB 4708c; MCSNB 4710; and MCSNB 4726a-b. †Parapholidophorus nybelini: MCSNB 3013 (holotype); MCSNB 431; MCSNB 2889 to MCSNB 2897; MCSNB 2898; MCSNB 2900; MCSNB 2920; MCSNB 2938; MCSNB 2959; MCSNB 2962; MCSNB 2963; MCSNB 2966; MCSNB 2978; MCSNB 2982; MCSNB 2985; MCSNB 2992; 
MCSNB 3001; MCSNB 3005; MCSNB 3072; MCSNB 3090; MCSNB 3213; MCSNB 3011; and MCSNB 4797g. †Parapholidophorus caffi: MCSNB 563 (holotype). $\uparrow$ Pholidoctenus serianus: MCSNB 3067 (holotype); MCSNB 2875 to 2877; MCSNB 3012; MCSNB 3034 to 3063; MCSNB 3064a-m; MCSNB 3065; 3066; 3068 to 3070 ; MCSNB 3095; MCSNB 3097 to 3090; MCSNB 3312 to 3315 ; MCSNB 3357; and MCSNB 3373 to 3378. $\uparrow$ Pholidophoretes salvus: NHMW 2007z170/0293a and b (holotype); NHMW 2007z0170/0094; NHMW 2007z0170/0095; NHMW 2007z0170/0296 to NHMW 2007z0170/0339). †Pholidophorus latiusculus: Innsb. F123 (neotypus); Innsb. 6b, 6c; Innsb. 27a; Innsb. 126b; Innsb. 128a; Innsb. 128b (belonging to two different specimens); GBA 2006/096/0024; and NHMUK P1063. $\uparrow$ Pholidorhynchodon malzanii: MCSNB 3385 (holotype); MCSNB 3161; MCSNB 3164; MCSNB 3243; MCSNB 3244; MCSNB 3274; MCSNB 3276; MCSNB 3281; MCSNB 3284; MCSNB 3285; MCSNB 3286; MCSNB 3287; MCSNB 3353; MCSNB 3381; MCSNB 3386; MCSNB 3285; MCSNB 3286; MCSNB 3392; MCSNB 3848; MCSNB 3859; MCSNB 3862; MCSNB 3887; and MCSNB 3914. †Zambellichthys bergamensis: MCSNB 4446 (holotype); MCSNB 4332b. $\dagger$ Eurycormidae: $\uparrow$ Eurycormus speciosus: BSPG AS V510 and BSPG 1960 XVIII 106; JME SOS 2339; JME SOS 2341; JME 3004; and JME 4615. SMNS 80144/37; SMNS 87316/3; SMNS 87848/21; SMNS 88987/3; SMNS 95445/11; SMNS 95445/12.

$\dagger$ Dorsetichthyiformes. $\uparrow$ Dorsetichthys (= Pholidophorus) bechei: FMNH 2137. MB f.3504 and MB f.19219. SMNS P 944. MCZ 9873; MCZ 6301; and MCZ 12056.

$\uparrow$ Leptolepidiformes. †Leptolepis coryphaenoides: SMNS 87381; SMNS 87382; and SMNS 87383 (these three specimens are originals from Bonn, 1830). BGHan 1931-4; BGHan 1956-8; BGHan 1957-2; BGHan 1957-5; and BGHan 1960 (acid-prepared specimens). GOE uncatalogued, many articulated and disarticulated specimens. Many disarticulated bones prepared for SEM.

$\uparrow$ Ascalaboidiformes. $\uparrow$ Ascalabos voithii: JME SOS 537 (neotype). CBM 9491. CMMH 9491. JME 537; JME SOS 1961/122; JME SOS 2362; JME SOS 2363 JME SOS 2364; JME SOS 2365; JME SOS 2458; JME SOS 2483; JME SOS 2496; JME SOS 2497; JME SOS 2886 (peels of scales); and many other specimens deposited at the JME. NHM 3672; NHM 3673a; NHM 37062; and NHM 37080. SHL, collection of H. Leich (Bochum, Germany) currently deposited in Tierpark und Fossilium Bochum (Bochum). SMNH P5683. †Ebertichthys ettlingensis: JME ETT 108a and 108b (holotype); JME ETT 11; JME ETT 24; JME ETT 60; JME ETT 61; JME ETT 64a; JME ETT 132a, b; JME ETT 148; and JME ETT 847a. †Tharsis dubius: BSPG 1964 XXIII 280; CBM 4845. FMNH 25076; and FMNH 25124. JME, many specimens from different localities.

$\uparrow$ Crossognathiformes. $\uparrow$ Bavarichthys incognitus: JME SOS 4934a/b. †Chongichthys dentatus: LBUCH 021778a-b and LBUCH 15-010277a-b. †Domeykos profetaensis: LBUCH 12-260972a$\mathrm{b}$ and LBUCH 01277-13a-3b. †Protoclupea atacamensis: LBUCH 1-250277a. †Protoclupea chilensis: R-396a, R396b and LBUCH 190179a-b. †Varasichthys ariasi: LBUCH 16-260972a-b; LBUCH 012378a; LBUCH 020778a; and LBUCH 020778b. And many other specimens of $\uparrow$ Varasichthys. $\dagger$ Ichthyodectiformes. $\uparrow$ Allothrissops mesogaster: FMNH-PF UC 2021 and FMNH-PF UC 2082; JME SOS 1941/17a; SMNH P 976; SMNH P 2925; and SMNH P 7733. †Pachythrissops propterus: BSPG 1986 XXIII 154; JME SOS 741; MB. f. 3505. †Thrissops $\mathrm{cf}$ †T. formosus: JME SOS 3024. $\uparrow$ Thrissops subovatus: JME SOS 1953/14a. †Thrissops cf. T. subovatus: JME SOS 2557.

Elopocephala or Teleocephala (or crown-group Teleostei)

Elopomorpha

Elopiformes. $\uparrow$ Anaethalion angustus: JME SOS 2271; JME SOS 2259; JME SOS 2260; JME SOS 2261a; and JME SOS 2261b. †Anaethalion angustissimus: JME SOS 2271; GPIT/ OS/891; GPIT/OS/1074/1; GPIT/OS/1074/2; and GPIT/OS/Y 1930. †Anaethalion knorri: JME SOS 2267a-b; JME SOS 2270; and JME SOS 2282. Elops affinis: SIO 69-167, 1 cl\&st, $121 \mathrm{~mm}$ SL. UCLA W 50-29, 4 cl\&st., 121.3, 128.4, 157.0, and $165.0 \mathrm{~mm}$ SL. Elops hawaiensis: CAS(SU) 35105, partially disarticulated skl, braincase of about $90 \mathrm{~mm}$ length; OS 5105, 2 cl\&st leptocephalous larvae, 26.7 and $32.5 \mathrm{~mm}$ SL. Elops saurus: ANSP 147401, 2 cl\&st, 97.8 and $99.1 \mathrm{~mm} \mathrm{SL}$; CAS(SU) 10847, skl, $\pm 395 \mathrm{~mm}$ SL; TCWC 0503.1, 5 cl\&st, 24.0, 24.0, 26, 30.0, and $35.0 \mathrm{~mm}$ SL; TCWC 0782.1, 3 cl\&st., 35.7, 43, and $46.4 \mathrm{~mm} \mathrm{SL;} \mathrm{TCWC}$ 2452.2, 5 cl\&st, 60.1, 97.3, 107, 110.4 and 154 mm SL; UNC 82/8, 2 cl\&st, 57 and $76 \mathrm{~mm}$ SL. $\uparrow$ Elopsomolos frickhingeri: JME SOS 4393. †Elopsomolos sp.: NMH 37048. Megalops atlanticus: UF 171286, 5 cl\&st, 26.3, 27.8, 29.1, 29.8, 40.5 mm SL; UF 208605, 5 cl\&st, 25.5, 31, 32.7, 41.1, and $44.5 \mathrm{~mm}$ SL; UF 208780, 3 cl\&st, 85, 90.4, and $122.5 \mathrm{~mm}$ SL. Megalops cyprinoides: CAS 145216, 2 cl\&st, $17.5 \mathrm{~mm}$ and $34.5 \mathrm{~mm}$ SL.

Albuliformes. Albula vulpes: AMNH 56840, skl, $\pm 292 \mathrm{~mm}$ SL; AMNH 56743, skl, $\pm 300 \mathrm{~mm} \mathrm{SL}$; and AMNH 56878, skl, \pm $305 \mathrm{~mm}$ SL; UCLA W58-96, 2 cl\&st, 195 and $220 \mathrm{~mm}$ SL. UCLA W49-122, 5 cl\&st, 46.7, 54.6, 63.5, 72.7, and $88.8 \mathrm{~mm}$ SL; UCLA W 49-122, 4 cl\&st leptocephalous larvae.

Anguilliformes. Anguilla rostrata: KU:KUI 5029, 6 cl\&st, 50, $50.4,53.8,55,82.5$, and $103.0 \mathrm{~mm} \mathrm{SL}$.

\section{Osteoglocephala or Osteoglossocephalai}

Osteoglossomorpha: $\dagger$ Lycopteriformes. $\uparrow$ Lycopteridae: $\uparrow L y$ coptera davidi: LACM 4959-122316 and LACM 4959-122317. SMNH P 6553. †Lycoptera cf. L. sinensis: FMNH 1291a and FMNH 1291b.

Hiodontiformes. Hiodon alosoides: JFBM 43312, $1 \mathrm{skl}, \pm 400$ mm SL; JFBM 43306, 1 skl, \pm 380 mm SL; KU:KUI 7618, 7 cl\&st, from 22.0 to $56.0 \mathrm{~mm} \mathrm{SL}$; KU:KUI $9618,7 \mathrm{cl} \& s t$, from 22 to 55 mm SL; KU:KUI uncat. 3 cl\&st, 68, 70, and 72 mm SL; KU:KUI 9661, 2 cl\&st, 59 and $67 \mathrm{~mm} \mathrm{SL}$; KU:KUI 13993, 2 cl\&st, 200 and 305 mm SL. Hiodon tergisus: KU:KUI 9662, 3 cl\&st, 48.6, 51.8, and $55.7 \mathrm{~mm} \mathrm{SL}$.

Osteoglossiformes. Osteoglossum ferreirai: KU:KUI 22650, 1 cl\&st, 52.3 mm SL. Pantodon buchholzi: KU:KUI 22651, 1 cl\&st, $50.0 \mathrm{~mm} \mathrm{SL}$.

\section{Clupeocephala}

Otomorpha

Clupeiformes. Alosa chrysochloris: KU:KUI 9634, 2 cl\&st, 43.7 and $54.3 \mathrm{~mm}$ SL. Anchoa mitchilli: KUI 7494, 2 cl\&st, disarticulated specimens; KU:KUI 17183, 2 cl\&st, disarticulated specimens. Brevoortia patronus: KU:KUI 15113, 5 cl\&st, disar- 
ticulated specimens. Coilia nasus: KU:KUI 40362, 33 cl\&st (15 larvae between 10.2 and $22.7 \mathrm{~mm} \mathrm{SL} ; 9$ between 16.6 and $30.1 \mathrm{~mm}$ SL; 9 specimens between 63.5 and 103.1 SL). Dorosoma cepedianum: KU:KUI 12100, 3 cl\&st, 30.5, 67, and 71.6 mm SL; KU:KUI 16167, 1 cl\&st, 46.9 mm SL; KU:KUI 21801, 169 cl\&st (100 sps. from $8 \mathrm{~mm}$ notochordal length (NL) to $15 \mathrm{~mm}$ SL and 69 sps. from 13.9 to $29.5 \mathrm{~mm} \mathrm{SL}$ ). Dorosoma petenense: KU:KUI 9594, 2 cl\&st, 27.3 and $34.5 \mathrm{~mm}$ SL. Engraulis encrasicolus: KU:KUI 19941, 8 cl\&st, 25 to $50 \mathrm{~mm}$ SL. Engraulis ringens: KU:KUI 19347, 10 cl\&st, disarticulated specimens. Ethmidium maculatum: KU:KUI 19349, 2 cl\&st, disarticulated large specimens. Jenkinsia lamprotaenia: KU:KUI 40364, $10 \mathrm{cl} \&$ st, from 34.5 to $49.1 \mathrm{~mm}$ SL. Lile stolifera: KU:KUI 5411, 3 cl\&st, 29.5, 45.6, and $52.2 \mathrm{~mm}$ SL; UCLA 58-307, 3 cl\&st, 71.7, 80, and $88.1 \mathrm{~mm}$ SL. Sardinops sagax: KU:KUI 19345, 6 cl\&st larvae, 14 to $19 \mathrm{~mm} \mathrm{Sl}$, and $4 \mathrm{cl} \& \mathrm{st}$ disarticulated large specimens. Denticipitidae: Denticeps clupeoides: MRAC M.T. 76-32-P-4915-932, 1 cl\&st, 29.1 mm SL; MRAC M.T. 76-44-P-7, 1 cl\&st, 18.5 mm SL.

Alepocephaliformes. Alepocephalus agassizii: VIMS 6606, 1 cl\&st, 100.9 mm SL. Alepocephalus tenebrosus: SIO 91-80, 124 and $154 \mathrm{~mm} \mathrm{SL}$; UW 042217 \#3, 3 cl\&st, 87.7, 119.0 and 150.0 mm SL; UW 042217 \#4, 1 cl\&st, 363.0 mm SL. Bathylaco nigricans: SIO 91-19, 1 cl\&st partially disarticulated; SIO 64-15-8, 1 cl\&st partially disarticulated. Bajacalifornia burragei: SIO 53235, 2 cl\&st, 91.7 and $79.6 \mathrm{~mm}$ SL; SIO 69-489, 1 cl\&st, 133.7 $\mathrm{mm}$ SL. Bathytroctes microlepis, $1 \mathrm{cl \& st}, 61.3 \mathrm{~mm}$ SL. Holtbyrnia latifrons: SIO 71-112, 1 cl\&st, $59.6 \mathrm{~mm}$ SL. Mirorictus caningi: SIO 66-20, 1 cl\&st, 91.5 mm SL. Mirorictus taaning: SIO 82-85, $97.8 \mathrm{~mm}$ SL. Paraholtbyrnia cyanocephala, SIO 077, 1 cl\&st, 126.4 mm SL. Pellisolus eubranchus: SIO 60-287, 1 cl\&st, 93 mm SL. Photostylus pycnopterus: VIMS 15368, 1 cl\&st, 49.9 mm SL. Sagamichthys abei: SIO 66-468, 1 cl\&st partially disarticulated. Searsia koefoedi: SIO 77-38, 1 cl\&st, 115.9 mm SL; SIO 77-53, 1 cl\&st, 117.9 mm SL. Searsioides multispinus: SIO077-21, 1 cl\&st, aprox. $100 \mathrm{~mm}$ SL. Talismania aphos: SIO 72-141, $1 \mathrm{cl \& st,} 103.8$ mm SL. Talismania bifurcata: KUI 41394, 1 cl\&st, 16.7 mm SL; KUI 41395, 1 cl\&st, 28.2 mm SL; SIO 56-68, 4 cl\&st, 18.9, 23.2, 25.8 and 30.6; SIO 64-1027, 2 cl\&st, 67.4 and $71.4 \mathrm{~mm}$ SL. Xenodermichthys copei: VIMS 3550, $1 \mathrm{cl} \& \mathrm{st}, 82.1 \mathrm{~mm}$ SL.

Ostariophysi incertae sedis. $\dagger$ Tischlingerichthys viohli: JME Moe 8.

\section{Ostariophysi}

Gonorynchiformes. Chanos chanos: CAS(SU) 35075, 1 skl, disarticulated, braincase of $148 \mathrm{~mm}$ length; KUI 39848 to 38796, day-to-day series of about 200 specimens from about $4 \mathrm{~mm}$ to $10 \mathrm{~mm}$ notochordal length and from 7.0 to $83.5 \mathrm{~mm} \mathrm{SL}$; KU:KUI 40365, 4 skl, 370.0 and $376.0 \mathrm{~mm}$ SL and 4 cl\&st, 150.0, 180.0, 330.0, and $400.0 \mathrm{~mm}$ SL; SIO 80-199, 7 cl\&st, from 16.1 to $44.5 \mathrm{~mm} \mathrm{SL}$. Gonorynchus abbreviatus: CAS 30993, $1 \mathrm{cl} \& \mathrm{st}, 150.0 \mathrm{~mm}$ SL.

Cypriniformes. Aspius aspius: ROM 52742, 4 cl\&st, 26.7, 35.8, 51.8, and 59.8 mm SL. Barbatula barbatula: ROM 49713, 5 cl\&st, 49.8, 60.9, 64.1, 66, and $75 \mathrm{~mm}$ SL. Carpiodes carpio: KU:KUI 21807, $24 \mathrm{cl} \& s t, 13.3$ to $42.3 \mathrm{~mm}$ SL. Carpiodes microstomus: FMNH 35171, 4 cl\&st, 34.8, 38.8, 40.5, and $45.7 \mathrm{~mm}$ SL. Catostomus commersoni: JFBM 11495, $7 \mathrm{cl} \&$ st, from 22.3 to 31.0 mm SL; JFBM 41727, skl, \pm 278.0 mm SL; KUI 38655, +100 cl\&st, between 12.0 to $21.3 \mathrm{~mm}$ SL; KUI 40245, day-to-day ontogenetic series of about 100 specimens, between 6 and $27.9 \mathrm{~mm}$ SL. Cobitis lutheri: KUI 38976, 2 cl\&st, 55.6 and $81.5 \mathrm{~mm} \mathrm{SL}$. Cycleptus elongatus: KUI 40695, 1 cl\&st, 148 mm SL; KU:KUI uncat. 6 cl\&st, 12.5, 13, 20.2, 20.3, 20.7, 20.8 mm SL. Cyprinus carpio: FMNH 42392, 1 cl\&st, 85.5 mm SL; KUI 3739, 1 cl\&st, $80.0 \mathrm{~mm}$ SL; JFBM, skl, $\pm 354.0 \mathrm{~mm}$ SL. Danio rerio: KU:KUI uncat., 17 cl\&st, 4.8, 5.3, 5.4, 5.5, 5.7, 5.8, 6, 6.6, and $6.8 \mathrm{~mm}$ SL. Hemiculter leucisculus: MCZ 32394, 2 cl\&st, 90.8 and 97.2 mm SL. Labeo batesii: USNM 303704, 4 cl\&st, 89.7, 95, 195.5, and $197.4 \mathrm{~mm}$ SL. Lepidomeda mollispinus: KU:KUI 11768, 20 cl\&st, from 54.8 to $68.7 \mathrm{~mm}$ SL. Luxilus zonatus: KU:KUI uncat., 11 cl\&st, 9, 9.7, 10.1, 10.3, 11, 18.2, 14, and 24.7 mm SL. Misgurnus anguillicaudatus: FMNH 57343, 5 cl\&st, 47.0, 50.1, 50.7, 53, and $80.5 \mathrm{~mm}$ SL; KUNHM 21447, 2 cl\&st, 96.2 and $100.3 \mathrm{~mm}$ SL. Notropis atherinoides: FMNH 72149, 20 cl\&st, from 20.2 to 55.5 mm SL. Opsariichthys bidens: CAS(SU) 32512, 2 cl\&st, 81.9 and $117.6 \mathrm{~mm}$ SL. Opsariichthys uncirostris: KU:KUI 21448, 4 cl\&st, 25.0, 29.6, 36.6, and $70.4 \mathrm{~mm}$ SL. Parabramis pekinensis: USNM 86494, 5 cl\&st, 49.0, 50.5, 54.7, 58.5, and 59.1 mm SL. Sabanejewia balcanica: FMNH 63814, 3 cl\&st, 33.9, 36.8, and $58 \mathrm{~mm}$ SL. Semotilus atromaculatus: KUI 12594, 5 cl\&st, 39.0, 41.0, 42.0, 42.0, 45.0, and $47.0 \mathrm{~mm}$ SL. Squaliobarbus curriculus: AMNH 10890, 2 cl\&st, 112.6 and $136.0 \mathrm{~mm}$ SL. Only a few cypriniforms are listed here from more than 150 species with cl\&st specimens included in the Tree of Life of Cypriniformes.

Characiformes. Astyanax sp.: KUI 20099, $6 \mathrm{cl \& st,} 18.8$ to $19.9 \mathrm{~mm}$ SL. Brycon argenteus, KUI 10543, 3 spec. Cheirodon pisciculus: LBUCH uncat., $30 \mathrm{cl} \& \mathrm{st}, 20.0$ to $55.0 \mathrm{~mm}$ SL. $\mathrm{Ho}$ plias malabaricus KU:KUI 13636, 3 cl\&st, partially disarticulated; KU:KUI 13646, 2 cl\&st, partially disarticulated. Xenocharax spilurus: CAS(SU) 15639, 2 cl\&st, 74.7 and $92 \mathrm{~mm} \mathrm{SL}$

Siluriformes. Diplomystes nahuelbutaensis: MNHN-Stg uncat., 4 cl\&st, 150.0 to $180.0 \mathrm{~mm}$ SL. Diplomystes viedmensis: FMNH 58004, 2 cl\&st, 80.5 and 91.7 mm SL. See Arratia, Quezada-Romegialli (2017) for a list of diplomystids. Noturus exilis: KU:KUI 17229a, 10 cl\&st larvae, from 10.0 to $12.0 \mathrm{~mm}$ SL. And many specimens belonging to Nematogenyidae, Loricariidae, Pimelodidae, and Trichomycteridae. See Arratia (1987, 1992, 1998). Arratia, Gayet (1995), and Arratia. Huaquín (1995) for lists of those catfishes and others.

Gymnotiformes. Gymnotus carapo: KU-KUI 13793, 9 cl\&st. Gymnotus cylindricus: KU:KUI 1869, 2 cl\&st. Brachyhypopomus brevirostris: KU:KUI 13800, 7 cl\&st. Hypopygus lepturus, KU:KUI 20127, 1 cl\&st.

\section{Euteleostei}

Esociformes. Esox americanus: KU:KUI 5227, caudal skeleton only, cl\&st; KU:KUI 17864, 4 cl\&st, 82.7, 89.5, 112.0, and 123.0 mm SL. Esox lucius: KU:KUI 19092, disarticulated skull, lower jaw $120.0 \mathrm{~mm}$ length, and caudal skeleton.

Salmoniformes. †Erichalcis arcta: UALVP 8598; UALVP 8602; UALVP 8606; and UALVP 8612. †Humbertia sp.: DMNH 2518-1. †Leptolepides haertesi: JME SOS 2473; JME SOS 2474; and JME SOS 2554. †Leptolepides sprattiformis: FMNH-PF 10984 and FMNH-PF 10986; JME SOS 2956; KUVP 60722 and KUVP 96128; SMNH P 1891; SMNS P 1894; SMNS 55106; and 
SMNS 55928. †Orthogonikleithrus hoelli: JME ETT 2301; JME ETT 2632; JME ETT 3954; JME ETT 3955; and JME ETT 3956. †Orthogonikleithrus leichi: JME SOS 2301 and JME SOS 2632. †Orthogonikleithrus sp.: JME ETT 30 and JME ETT 216. Oncorhynchus mykiss: KUNHM 12463, 7 cl\&st, from 28.0 to 43.0 mm SL; KU:KUI 21936, 20 cl\&st, 290.0 to $300.0 \mathrm{~mm}$ SL; OS uncat., day-to-day ontogenetic series of about $200.0 \mathrm{cl} \&$ st, from 13.0 $\mathrm{mm}$ NL to $73.0 \mathrm{~mm}$ SL. Prosopium cylindraceum: KU:KUI 15417 , 2 cl\&st, 300.0 and $310.0 \mathrm{~mm}$ SL. Prosopium williamsoni: KU:KUI 11817, 13 cl\&st, 12 larvae between 20.0 and $33.6 \mathrm{~mm}$ SL and 1 specimen of $230.0 \mathrm{~mm}$ SL. Thymallus arcticus: KU:KUI 15419, 3 cl\&st, 151.0, 166.0, and $177.0 \mathrm{~mm}$ SL. Umbra limi: KU:KUI 10370, 6 cl\&st, 22.5, 26.3, 27, 27.8, 52.0, and 54.4 mm SL.

Argentiniformes. Argentina sialis: SIO 66-4, 3 cl\&st, 119, 121.2 and $144.2 \mathrm{~mm}$ SL; SIO CR 5208, 4 cl\&st, 3 larvae of 9.0 to $14 \mathrm{~mm} \mathrm{NL}$, and 1 specimen of $13.5 \mathrm{~mm} \mathrm{SL}$.

\section{Acknowledgments}

My sincerest thanks to José Birindelli and the Organizing Committee of the II Symposium of Phylogeny and Classification of Neotropical Fishes (October-2017, Londrina, Brazil) for the invitation to participate in the meeting and to Luis Malabarba and Carla Pavanelli for their invitations to submit a manuscript for this special symposium volume. Special thanks to Philip Hasting, Benjamin Frable and Cynthia Klepado from Scripps Institution, La Jolla, CA; Eric Hilton and Sarah K. Huber from VIMS; Luke Tornabene and Katherine Pearson Maslenikov, University of Washington Fish Collection, School of Aquatic and Fishery Sciences and Burke Museum of Natural History and Culture, Seattle, WA for loans of alepocephaliforms of different sizes; and to William Watson from NOAA Southwest Fisheries, La Jolla, Ca for his generous donation of alepocephaliform larvae that made possible this research. To Andrew Bentley (University of Kansas) for curatorial assistance. To G. David Johnson and Jeff William (US National Museum and staff of the Division of Fishes) for loan of cleared and staining alepocephaliforms that R. Rosenblatt and T. Matsui (SIO) prepared some years ago, which were transferred to me as official loans from SIO. Diogo Mayrinck (Rio de Janeiro State University), who especially went to DNPM, Rio de Janeiro, to make high resolution photographs of the clupeomorph Santanaclupea silvasantosi to be used in this paper and to Rodrigo da Rocha Machado for granting facilities and permission. Jesus Alvarado-Ortega (National University of Mexico) kindly provided original photographs of Ranulfoichthys dorsonudum and Francisco Poyato-Ariza (Autonomous University of Madrid), provided unpublished photographs of Gordichthys conquensis. My special thanks to Małgorzata Bieńkowska-Wasiluk, who especially traveled to Wroclaw, Poland to take photographs of Carpathichthys and to Krzysztof Stefaniak and Ewa Swidnicka (ZPALWr), Wroclaw for given access to the specimens. I would like to thank especially to TJ Meehan for his revision of the style of the manuscript and his help with the preparation of the di- gital submission of the figures and to Claudio Quezada-Romegialli (University of Valparaiso, Chile) for his help with some of the photographs and in addition to Nicolás Cumplido (University of Chile) for their help with the digital preparation of some figures. To Hans-Peter Schultze for his critical comments to a previous version of the manuscript and to G. D. Johnson, Fabio di Dario, an anonymous reviewer, and the associate editor Brian Sidlauskas for reviewing it and offering constructive comments that improved the paper.

\section{References}

Albert JS, Reis RE, editors. Historical Biogeography of Neotropical Freshwater Fishes. Berkeley, Los Angeles, London: University of California Press; 2011.

Alvarado-Ortega J. Ancient herring from the Tlayúa Quarry (Cretaceous, Albian) near Tepexi de Rodríguez, Puebla State, central Mexico, closing the gap in the early diversification of Clupeomorpha. Cretaceous Res. 2014; 50:171-80.

Alvarado-Ortega J, Ovalles-Damian E, Arratia G. A review of the interrelationships of the order Ellimmichthyiformes (Teleostei: Clupeomorpha). In: Arratia G, Schultze H-P, Wilson MVH, editors. Mesozoic Fishes 4 - Homology and Phylogeny. München: Verlag Dr. F. Pfeil; 2008. p.257-278.

Amaral CRL, Alvarado-Ortega J, Brito PM. Sapperichthys gen. nov., a new gonorynchid from the Cenomanian of Chiapas, Mexico. In: Arratia G, Schultze H-P, Wilson MVH, editors. Mesozoic Fishes 5-Global Diversity and Evolution. München: Verlag Dr. F. Pfeil; 2013. p.305-324.

Arcila D, Ortí G, Vari RP, Armbruster JW, Stiassny MLJ, Ko $\mathrm{KD}$, Sabaj $\mathrm{MH}$ et al. Genome wide interrogation advances resolution of recalcitrant groups in the Tree of Life. Nature Eco Evo. 2017; 17:162. DOI: 10.1186/s12862-017-0958-3

Arratia G. El esqueleto caudal de los peces siluriformes y sus tendencias evolutivas (Fam. Diplomystidae y Trichomycteridae). Bol Mus Nac Hist Natur Chile. 1982; 38:49-61.

Arratia G. Basal teleosts and teleostean phylogeny. [PhD Thesis]. Uppsala: University of Uppsala; 1996.

Arratia G. Description of the primitive family Diplomystidae (Siluriformes, Teleostei, Pisces): morphology, taxonomy, and phylogenetic implications. Bonner zool Monogr. 1987; 24:1-120.

Arratia G. Development and variation of the suspensorium of primitive catfishes (Teleostei: Ostariophysi) and their phylogenetic relationships. Bonn zool Monogr. 1992; 32:1-149.

Arratia G. Basal teleosts and teleostean phylogeny. Palaeo Ichthyologica. 1997; 7:1-168.

Arratia G. The monophyly of Teleostei and stem group teleosts. In: Mesozoic Fishes - Systematics and Fossil Record. Arratia G, Schultze H-P, editors. München: Verlag Dr. F. Pfeil; 1999. p.265-334.

Arratia G. The sister-group of Teleostei: consensus and disagreements. J Vert Paleont. 2001; 21:767-73.

Arratia G. Clupeocephala re-visited: Analysis of characters and homologies. Revista Biol Mar \& Oceanogr. 2010; 45(Suppl.1):635-57.

Arratia G. Morphology, taxonomy, and phylogeny of Triassic pholidophorid fishes (Actinopterygii, Teleostei). J Vert Paleont. 2013; 33(Supl.):1-138. DOI: 10.1080/02724634.2013.835642

Arratia G. Complexities of Early Teleostei and the evolution of particular morphological structures through time. Copeia. 2015; 103(4):999-1025. 
Arratia G. New Triassic teleosts (Actinopterygii, Teleosteomorpha) from northern Italy and their phylogenetic relationships among the most basal teleosts. J Vert Paleont. 2017; Available from: https://doi.org/10.1080/02724634.2017.1312690

Arratia G, Cione LA. The fossil record of fossil fishes of Southern South America. In: Contributions of Southern South America to Vertebrate Paleontology. Arratia G, editor. Muenchner Geowiss. Abh.. München: Verlag Dr. F. Pfeil; 1996. p.9-72. (special volume)

Arratia G, Gayet M. Sensory canals and related bones of Tertiary siluriform crania from Bolivia and North America and comparison with Recent forms. J Vert Paleont. 1995; 15(3):482-505.

Arratia G, Huaquín L. Morphology of the lateral line system and of the skin of diplomystid and certain primitive loricarioid catfishes and systematic and ecological considerations. Bonner zool Monogr. 1995; 36:1-110.

Arratia G, Kapoor BG, Chardon M, Diogo R, editors. Catfishes. Enfield, NH: Science Publishers; 2003.

Arratia G, Quezada-Romegialli C. Understanding morphological variability in a taxonomic context in Chilean diplomystids (Teleostei: Siluriformes), including the description of a new species. PeerJ. 2017; 5(4):e2991; Available from: https://doi. org/10.7717/peerj.2991

Arratia G, Schultze H-P. Reevaluation of the caudal skeleton of certain actinopterygian fishes. III. Salmonidae. Homologization of caudal skeletal structures. J Morphol. 1992; 214(2):187-249.

Arratia G, Schultze H-P. Knochenfische im engeren Sinne (Teleostei). In: Solnhofen. Ein Fenster in the Jurazeit. Arratia G, Schultze H-P, Tischlinger H, Viohl G, editors. Munchen: Verlag Dr. F. Pfeil.; 2015. p.389-409.

Begle DP. Relationships of the osmeroid fishes and the use of reductive characters in phylogenetic analysis. Syst Zool. 1991; 40(1):33-53.

Begle DP. Monophyly and relationships of the argentinoid fishes. Copeia. 1992;1992(2):350-66.

Berg LS. 1937. Classification of fishes, both Recent and fossil. Travaux de l'Institute de l'Academie des Sciences de l'URSS. 1937; 5:87-517.

Berg LS. 1958. System der Rezenten und fossilen Fischartigen und Fische. Berlin: Veb Deutscher Verlag der Wissenschaften. p. 1-310.

Betancur-R R, Broughton RE, Wiley EO, Carpenter K, López JA, $\mathrm{Li} \mathrm{C}$ et al. The tree of life and a new classification of bony fishes. PLoS Curr. 2013; Available from: doi:10.1371/currents. tol.53ba26640df0ccaee75bb165c8c26288.

Betancur-R R, Wiley EO, Arratia G, Acero A, Bailly N, Miya $\mathrm{M}$ et al. Phylogenetic classification of bony fishes. BMC Evolutionary Biology. 2017; 17(162). Available from: https:// doi.org/10.1186/s12862-017-0958-3

Bloom DD, Lovejoy NR. The evolutionary origins of diadromy inferred from a time-calibrated phylogeny for Clupeiformes (herrings and allies). Proc R Soc B: Biol Sci. 2014; 281(1778). Available from: http://doi.org/10.1098/rspb.2013.2081

Brito PM, Amaral CRL. An overview of the specific problems of Dastilbe Jordan, 1910 (Gonorynchiformes: Chanidae) from the Lower Cretaceous of western Gondwana. In: Mesozoic Fishes 4 - Homology and Phylogeny. Arratia G, Schultze H-P, Wilson MVH, editors. München: Verlag Dr. F. Pfeil; 2008. p.279-294.

Chakrabarty P, Faircloth BC, Alda F, Ludt WB, McMahan CD, Near TJ, Dornburg A et al. Phylogenomic systematics of ostariophysan fishes: ultraconserved elements support the surprising non- monophyly of Characiformes. Syst Biol. 2017; 66(6):881-885. Available from: http://doi.org/10.1093/sysbio/syx038.

Chang M-M, Maisey JG. Redescription of Ellimma branneri and Diplomystus shengliensis, and relations of some basal clupeomorphs. Amer Mus Novitates. 203; 3404:1-35.

Chen WJ, Lavoué S, Mayden RL. Evolutionary origin and early biogeography of otophysan fishes (Ostariophysi: Teleostei). Evolution. 2013; 67(8):2218-39.

Davis MP, Arratia G, Kaiser TM. The first fossil shellear (Gonorynchiformes: Kneriidae) from the Eocene lake of Mahenge (Tanzania). In: Arratia G, Schultze H-P, Wilson MVH, editors. Mesozoic Fishes 5 - Global Diversity and Evolution. München: Verlag Dr. F. Pfeil; 2013. p.325-362.

Di Dario F. Evidence supporting a sister group relationship between Clupeoidea and Engrauloidea. Copeia. 2002; 2002:496-503.

Di Dario F. Homology between the recessus lateralis and cephalic sensory canals, with the proposition of additional synapomorphies for the Clupeiformes and the Clupeoidei. Zool J Linn Soc. 2004; 141(2):257-70. Available from: https://doi. org/10.1111/j.1096-3642.2004.00122.x

Di DarioF. Chirocentrids as engrauloids: evidence from suspensorium, branchial arches, and infraorbital bones (Clupeomorpha, Teleostei). Zool J Linnean Soc. 2009; 156(2):363-83.

Di Dario F, de Pinna MCC. The supratemporal system and the pattern of ramification of cephalic sensory canals in Denticeps clupeoides (Denticipitidae, Teleostei): Additional evidence formonophyly of Clupeiformes and Clupeoidei. Pap. Avulsos Zool. 2006; 46(10):107-23.

Dietze K. Redescription of Dastilbe crandalli (Chanidae, Euteleostei) from the Early Cretaceous Crato Formation in north-eastern Brazil. J Vert Paleont. 2007; 27(1):8-16.

Dingerkus G, Uhler LD. Enzyme clearing of alcian blue stained whole small vertebrates for demonstration of cartilage. Stain Technol. 1977; 52:229-32.

Diogo R. On the cephalic and pectoral girdle muscles of the deep sea fish Alepocephalus rostratus, with comments on the functional morphology and phylogenetic relationships of the Alepocephaloidei (Teleostei). Animal Biology. 2008; 58(1):23-9.

Filleul A, Maisey J. 2004. Description of Santanichthys diasii (Otophysi, Characiformes) from the Albian of the Santana Formation and comments on its implications for otophysan relationships. Amer Mus Novitates. 2004; 3455:1-21.

Fink WL. Basal euteleosts: Relationships. In: Ontogeny and Systematic of Fishes. Moser GH, Richards WJ, Cohen DM, Fahay MP, Kendall AW, Jr, Richarson SL, editors. Lawrence, KS: Amer. Soc. Ichthyol. Herpetol. 1984; p.2002-6.

Fink WL, Weitzman SH. Relationships of the stomiiform fishes (Teleostei), with a redescription of Diplophos. Bull Mus Comp Zool. 1982; 150:31-93.

Fink SV, Fink WL. Interrelationships of the Ostariophysan Fishes (Teleostei). Zool J Linnean Soc. 1981; 72(4):297-353.

Fink SV, Fink WL. Interrelationships of ostariophysan fishes (Teleostei). In: Interrelationships of fishes. Stiassny MLJ, Parenti LR, Johnson GD, editors. San Diego: Academic Press; 1996; p.209-249.

Fink SV, Greenwood PH, Fink WL. A critique on recent work on fossil ostariophysan fishes. Copeia. 1984; 1984(4):1033-41.

Forey PL. A three-dimensional skull of a primitive clupeomorph from the Cenomanian English Chalk, and implications for the evolution of the clupeomorph acusticolateralis system. In: Mesozoic Fishes 3 - Systematics, Paleoenvironments and Biodiversity. Arratia G, Tintori A, editors. München: Verlag Dr. F. Pfeil.; 2004. p.404-427. 
Fujita K. The Caudal Skeleton of Teleostean Fishes. Tokyo: Tokai Univ. Press; 1990.

Gayet M. Cypriniform crétacé en Amérique du Sud. Comptes Rendus hebdomadaires des Séances de l'Académie des Sciences de Paris. 1982; 295(3): 1037-40.

Gayet M. Contribution à l'étude anatomique et systématique de l'ichthyofaune Cénomanienne du Portugal. Comun Serv Geol Port. 1985; 71:91-118.

Gayet M, Meunier F. Premiáre découverte de Gymnotiformes fossils (Pisces, Ostariophysi) dans le Miocène supérieur de Bolivie. Comptes Rendue Acad Sci, Paris. 1991; 313:471-76.

Girone A. The Pleistocene bathyal teleostean fauna of Archi (Southern Italy): palaeoecological and palaeobiogeographic implications. Riv Italiana Paleont Strat. 2003; 109(1):99-110.

Girone A, Nolf D, Cappetta, H. Pleistocene fish otoliths from the Mediterranean Basin: a synthesis. Geobios. 2006; 39(5):651-71.

Gosline WA. Contributions toward a classification of modern isospondylous fishes. Bull British Mus Natur Hist, Zool. 1960; 6:265-327.

Grande L. Recent and fossil clupeomorph fishes with materials for revisions of the subgroups of clupeids. Bull Amer Mus Natur Hist. 1985; 181:231-372.

Grande L. Redescription of $\uparrow$ Hypsidoris farsonensis (Teleostei: Siluriformes) with a reassessment of its phylogenetic relationships. J Vert Paleont. 1987; 7:24-54.

Grande T, Arratia G. Morphological analysis of the gonorynchiform postcranial skeleton. In: Gonorynchiformes and Ostariophysan Relationships. Grande T, Poyato-Ariza FJ, Diogo R, editors. Enfield, NH: Science Publishers; 2010. p.39-71.

Grande T, Poyato-Ariza FJ, Diogo R, editors. Gonorynchiformes and Ostariophysan Relationships. Enfield, NH: Science Publishers; 2010.

Greenwood PH. Fossil denticipid fishes from East Africa. Bull Brit Mus Nat Hist, Geol.1960; 5:1-11.

Greenwood PH, Rosen DE, Weitzman SH, Myers GS. Phyletic studies of teleostean fishes with a provisional classification of living forms. Bull Amer Mus Natur Hist. 1966; 131(4):339-456.

Greenwood PH, Rosen DE. Notes on the structure and relationships of the alepocephaloid fishes. American Mus Novitates. 1971; 2473:1-48.

Grunbaum T, Cloutier R. Ontogeny, variation, and homology in Salvelinus alpinus caudal skeleton (Teleostei: Salmonidae). J Morphol. 2010; 271(1):12-24.

Harrison T, Msuya P, Murray AM, Jacobbs BF, Báez, AM et al. Paleontological investigations at the Eocene locality of Mahenge in North-Central Tanzania, East Africa. In: Unusual Occurrences and Rarely Sampled Habitats. Gunnel GF, editor. New York: Kluwer Academic/Plenum Publishers; 2001. p.39-74.

Ishiguro NB, Miya M, Nishida M. Basal euteleostean relationships: a mitogenomic perspective on the phylogenetic reality of the "Protacanthopterygii". Mol Phylog Evol. 2003; 27(3):476-88.

Jerzmaska A. Oligocene alepocephaloid fishes from the Polish Carpathians. Acta Paleontol Pol. 1979; 24(1):65-76.

Johnson GD, Patterson C. The gill arches of gonorynchiform fishes. South Afr J Sci. 1997; 93:594-600.

Johnson GD, Patterson C. Relationships of lower euteleostean fishes. In: Interrelationships of fishes. Stiassny MLJ, Parenti LR, Johnson GD, editors. San Diego: Academic Press; 1996. p.251-332.

Kaiser TM, Ansorge J, Arratia G, V. Bullwinkel V, Gunnell G, Herendeen PS et al. In: The maar lake of Mahenge (Tanzania) - unique evidence of Eocene terrestrial environments in
sub-Sahara Africa. Z Deut Gesells Geowissenschaf. 2006; 157(3):99-120.

Lauder GV, Liem KF. The evolution and interrelationships of the actinopterygian fishes. Bull Mus Comp Zool. 1983; 150:95-197.

Lavoué S, Konstantinidis P, Chen W-J. Progress in clupeiform systematics. In: Gania K, editor. Biology and Ecology of Sardines and Anchovies. VRC Press. Boca Raton, FL; 2014. p.3-42.

Lavoué S, Miya M, Inoue JG, Saitoh K, Ishiguro NB et al. Molecular systematics of the gonorynchiform fishes (Teleostei) based on whole mitogenome sequences: implications for higher-level relationships within the Otocephala. Mol Phyl Evol. 2005; 37(1):165-77.

Lavoué S, Miya M, Musikasinthorn P, Chen WJ, Nishida M. Mitogenomic evidence for an Indo-West Pacific origin of the Clupeoidei (Teleostei: Clupeiformes). PLoS One. 2013; 8(2):e56485.

Lavoué S, Miya M, Poulsen JY, Møller PR, Nishida M. Monophyly, phylogenetic position and interfamilial relationships of the Alepocephaliformes (Teleostei) based on whole mitogenome sequences. Mol Phyl Evol. 2008; 47(3):1111-21.

Lé HLV, Lecointre G, Perasso R. A 28S rRNA-based phylogeny of the gnathostomes: first steps in the analysis of conflict and congruence with morphologically based cladograms. Mol Phyl Evol. 1993; 2(1):31-51.

Lecointre G. Etude d l'impact de l'echantillonnage des espèces et de la longueur des séquences sur la robustesse des phylogénies moléculaires; implications sur la phylogénie des téléostéens. [PhD Thesis]. Paris: Université Paris VII, 1993.

Lecointre G, Nelson GJ. 1996. Clupeomorpha, sister-group of Ostariophysi. In: Interrelationships of Fishes. Stiassny MLJ, Parenti LR, Johnson GD, editors. San Diego: Academic Press; 1996. p.193-207.

Li C, Orti G. Molecular phylogeny of Clupeiformes (Actinopterygii) inferred from nuclear and mitochondrial DNA sequences. Mol Phyl Evol. 2007; 44(1):386-398.

Lunberg JG, Baskin JN. The caudal skeleton of catfishes, order Siluriformes. Amer Mus Novitates. 1969; 2399:1-49.

Maisey J. A new clupeomorph fish from the Santana Formation (Albian) of NE Brazil. Amer Mus Novitates. 1993; 3076:1-15.

Malabarba LR, Di Dario F. A new predatory herring-like fish (Teleostei: Clupeiformes) from the Early Cretaceous of Brazil, and implications for relationships in the Clupeoidei. Zool J Linn Soc. 2017; 180(1):175-94.

Malabarba LR, Reis RE, Vari RP, Lucena ZMS, Lucena CAS, editors. Phylogeny and Classification of Neotropical Fishes. Porto Alegre: EDIPUCRS; 1998.

Malabarba MC, Malabarba LR. Biogeography of Characiformes: an evaluation of the available information of fossil and extant taxa. In: Origin and Phylogenetic Interrelationships of Teleosts. Nelson JS, Schultze H-P, Wilson MVH, editors. München: Verlag Dr. F. Pfeil; 2010. p.317-336.

Markle DF. Preliminary studies on the systematics of deep-sea Alepocephaloidea (Pisces: Salmoniformes). PhD Thesis, Virginia: The College of William and Mary. 1976.

Mayrinck D, Brito PM, Otero O. Anatomical review of Salminops ibericus, a Teleostei incertae sedis from the Cenomanian of Portugal, anciently assigned to Characiformes and possibly related to crossognathiform fishes. Cretaceous Res. 2015b; 56:66-75.

Mayrinck D, Brito PM, Otero O. Review of the osteology of the fossil fish formerly attributed to the genus Chanoides and implications for the definition of otophysan bony characters. J Syst Paleont. 2015a; 13(5):1-24. 
Mayrinck, D, Brito PM, Meunier FJ, Alvarado-Ortega J, Otero O. $\uparrow$ Sorbinichthys verraesi: An unexpected case of a benthic fish outside Acanthomorpha in the Upper Cretaceous of the Tethyan Sea. PlosOne. 2017; 12(8):e0183879. Available from: https://doi.org/10.1371/journal.pone.0183879

Monod T. Le complexe urophore des poisons téléostéens. Mém Inst Fondament. Afrique Noire. 1968; 81:1-705.

Murray AM, Wilson MVH. Two new paraclupeid fishes (Clupeomorpha: Ellimmichthyiformes) from the Upper Cretaceous of Morocco. In: Mesozoic Fishes 5- Global diversity and Evolution, Arratia G, Schultze H-P, Wilson MVH, editors. München: Verlag Dr. F. Pfeil; 2013. p.267-290.

Nakatani M, Miya M, Mabuchi K, Saitoh K, Nishida M. Evolutionary history of Otophysi (Teleostei), a major clade of the modern freshwater fishes: Pangaean origin and Mesozoic radiation. BMC Evol Biol. 2011; 11:177. Available from: https://doi.org/10.1186/1471-2148-11-177

Near TJ, Eytan RI, Dornbur A, Kuhn KL, Moore JA, Davis PM et al. Resolution of ray-finned fish phylogeny and timing of diversification. Proc Nat Acad Sciences USA. 2012; 109(34):13698-13703.

Nelson GJ. Epibranchial organs in lower teleostean fishes. J Zool, London. 1967; 153:71-89.

Nelson JS. Fishes of the World. 3rd ed.. Hoboken: John Wiley \& Sons; 1994.

Nelson JS: Fishes of the World. 4thed. Hoboken: John Wiley \& Sons; 2006.

Nelson JS, Grande T, Wilson MVH. Fishes of the World. 5th ed. Hoboken: John Wiley \& Sons; 2016.

Nybelin O. The polyural skeleton of Lepisosteus and certain other actinopterygians. Zool Scripta. 1977; 6(3):233-44.

Patterson, C. Two Upper Cretaceous Salmoniform fishes from the Lebanon. Bull Brit Mus Nat Hist, Geol. 1970; 19:205-96.

Patterson C, Rosen DE. Review of ichthyodectiform and other Mesozoic teleost fishes and the theory and practice of classifying fossils. Bull Amer Mus Natur Hist. 1977; 158:81-172.

de Pinna MCC. Teleostean monophyly. In: Interrelationships of fishes. Stiassny MLJ, Parenti LR, Johnson GD, editors. San Diego: Academic Press; 1996. p.147-162.

de Pinna MCC, di Dario F. The branchial arches of the primitive clupeomorpzh fish, Denticeps clupeoides, and their phylogenetic implication (Clupeiformes, Denticipitidae). In: Origin and Phylogenetic Interrelationships of Teleosts. Nelson JS, Schultze H-P, Wilson MVH, editors. München: Verlag Dr. F. Pfeil; 2010. p.251-268

Poulsen JY, Møller PR, Lavoué S, Knudsen SW, Nishida M, Miya M. Higher and lower-level relationships of the deep-sea fish order Alepocephaliformes (Teleostei: Otocephala) inferred from whole mitogenome sequences. Biol J Linn Soc. 2009; 98(4):923-36.

Poyato-Ariza FJ, Grande T, Diogo R: Gonorynchiform interrelationships: Historic overview, analysis, and revised systematics of the group. In: Gonorynchiformes and Ostariophysan Relationships. Grande T, Poyato-Ariza FJ, Diogo R, editors. Enfield, NH: Science Publishers; 2010. p.227-338.

Reis RE, Kullander SO, Ferraris Junior CJ, editors. Check list of the Freshwater Fishes of South and Central America. CLOFFSA. Fish Base Data of Neotropical Fishes. Porto Alegre: Edipucrs; 2003.

Rosen DE. Interrelationships of higher euteleostean fishes. In: Interrelationships of Fishes. Greenwood PH, Miles RS, Patterson C, editors. London: Academic Press; 1973. p.397-513.
Rosen DE. Phylogeny and zoogeography of salmoniform fishes and relationships of Lepidogalaxias salamandroides. Bull Amer Mus Natur Hist. 1974; 153:265-326.

Rosen DE. Teleostean interrelationships, morphological function and evolutionary inference. Amer Zool. 1982; 22:261-73.

Rosen DE. An essay on euteleostean classification. Amer Mus Novitates. 1985; 2827:1-57.

Rosen DE, Greenwood PH. Origin of the Weberian apparatus and the relationships of ostariophysans and gonorynchiform fishes. Amer Mus Novitates. 1970; 2428:1-25.

Sabaj Perez MH. Standard symbolic codes for institutional resource collections in herpetology and ichthyology: an online reference. Version 5.0. American Society of Ichthyologists and Herpetologists. Available at http://www.asih.org (accessed on 22 September 2014).

de Santana CD, Vari RP, Wosiacki WB. The Untold Story of the Caudal Skeleton in the Electric Eel (Ostariophysi: Gymnotiformes: Electrophorus. PLoS ONE. 2013; 8(7):e68719. Available from: https://doi.org/10.1371/journal.pone.0068719

Schultze H-P, Arratia G. Reevaluation of the caudal skeleton of teleosts (Actinopterygii, Osteichthyes). - Zool J Linn Soc. 1989; 97(3):189-231.

Schultze H-P, Arratia G. The caudal skeleton of basal teleosts, its conventions, and some of its major evolutionary novelties in a temporal dimension. In: Mesozoic Fishes 5 - Global Diversity and Evolution. Arratia G, Schultze H-P, Wilson MVH, editors. München: Verlag F. Pfeil, 2013. p.187-246.

Sullivan JP, Lundberg JG, Hardman M. A phylogenetic analysis of the major groups of catfishes (Teleostei: Siluriformes) using rag1 and rag2 nuclear gene sequences. Mol Phyl Evol. 2006; 41(3):636-62.

Swofford DL, Maddison D. Reconstructing ancestral character states under Wagner parsimony. Math Biosci. 1987; 87(2):199229.

Whitehead PJP. Clupeoid fishes of the world (suborder Clupeoidei). Part 1. Chirocentridae, Clupeidae and Pristigasteridae. FAO Species Catalogue, 7. FAO Fish Synop. 1985; 7:1-303.

Whitehead PJP, Nelso GJ, Wongrata T. Clupeoid fishes of the world (suborder Clupeoidei). Part 2. Engraulididae. FAO Species Catalogue, 7. FAO Fish Synop. 1988; 7:305-579.

Wiley EO, Fuiten AM, Doosey MH, Lohman BK, Merkes C, Azuma M. The caudal skeleton of the zebrafish, Danio rerio, from a phylogenetic perspective: A polyural interpretation of homologous structures. Copeia. 2015; 103(4):740-750.

Wiley EO, Johnson GD. A teleost classification based on a monophyletic group. In: Origin and Phylogenetic Relationships on Teleosts. Nelson JS, Schultze H-P, Wilson MVH, editors. München: Verlag. Dr. F. Pfeil; 2010. p.123-182.

Wiley EO, Lieberman BS. Phylogenetics. Theory and Practice of Phylogenetic Systematics. Hoboken: New Jersey, John Wiley \& Sons, Inc.; 2011.

Zaragueta-Basil R. Basal clupeomorphs and ellimmichthyiform phylogeny. In: Mesozoic Fishes 3 - Systematics, Paleoenvironments and Biodiversity. Arratia G, Tintori A, editors. München: Verlag. Dr. F. Pfeil; 2004. p.391-404. 